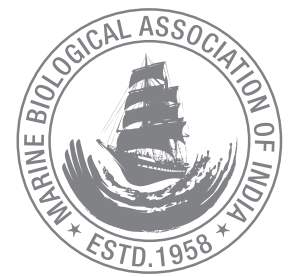

\title{
Biodiversity of sponges (Phylum: Porifera) off Tuticorin, India
}

\author{
M. S. Varsha ${ }^{1,4}$, L. Ranjith ${ }^{2}$, Molly Varghese ${ }^{1}$, K. K. Joshi ${ }^{*}$, M. Sethulakshmi', \\ A. Reshma Prasad', Thobias P. Antony', M.S. Parvathy', N. Jesuraj ${ }^{2}$, P. Muthukrishnan' ${ }^{2}$, \\ I. Ravindren ${ }^{2}$, A. Paulpondi ${ }^{2}$, K. P. Kanthan ${ }^{2}$, M. Karuppuswami², Madhumita Biswas ${ }^{3}$ \\ and A. Gopalakrishnan ${ }^{1}$ \\ ${ }^{1}$ ICAR-Central Marine Fisheries Research Institute, Kochi-682018, Kerala, India. \\ ${ }^{2}$ Regional Station of ICAR-CMFRI, Tuticorin-628 001, Tamil Nadu, India. \\ ${ }^{3}$ Ministry of Environment Forest and Climate Change, New Delhi-110003, India. \\ ${ }^{4}$ Cochin University of Science and Technology, Kochi-682022, India. \\ *Correspondence e-mail: joshyguru@gmail.com
}

\begin{abstract}
The present study deals with 18 new records of sponges found at Kayalpatnam area and a checklist of sponges reported off Tuticorin in the Gulf of Mannar. The new records are Aiolochoria crassa, Axinella damicornis, Clathria (Clathria) prolifera, Clathrina sororcula, Clathrina sinusarabica, Clathrina coriacea, Cliona delitrix, Colospongia auris, Crella incrustans, Crambe crambe, Hyattella pertusa, Plakortis simplex, Petrosia (Petrosia) ficiformis, Phorbas plumosus, Spheciospongia vesparium, Spirastrella cunctatrix, Xestospongia muta and Sycon ciliatum. Details about the species diversity of common sponges, invasive sponges,massive sponges and boring sponges of the area are discussed and presented.
\end{abstract}

Keywords: Marine sponges, Demospongiae, boring sponges, coral Islands

\section{Introduction}

Gulf of Mannar (GOM) is known for its rich biodiversity of fauna and flora and a source of inspiration for research and innovation. Gulf of Mannar Biosphere Reserve (GOMBR) with an area of $10500 \mathrm{~km}^{2}$ have 21 coral islands and seven of them occur in the Vaippar - Tuticorin area. Tuticorin area is characterized by the presence of hard rocky bottom, soft muddy bottom, lagoon and lakes. Thiruchendur to Tuticorin region of GOM-up to a distance of 25 nautical miles from shore 8-10 m depth zone-is characterized by a narrow belt of submerged dead coral blocks which serves as a very good substrate for sponges. Patches of coral ground "Paar" in the 10-23 m depth zone, available in an area of 10-16 nautical miles from land are pearl oyster beds (Mahadevan and Nayar, 1967; Nayar and Mahadevan, 1987) which also forms a good habitat for sponges.

First detailed report of the fauna of Pearl oyster beds of Tuticorin area was made by Hornell (1922). The first extensive collection from Tuticorin area was made by Prof. Herdman in 1902 which was later published by Dendy (1905). Relationship between the pearl oyster beds and sponge fauna have been reported in earlier works (Herdman, 1903-1906; Hornell, 1905, 1922; Mahadevan and Nayar 1967, 1974; Nayar and Mahadevan, 1964, 1987). The sponges of Tuticorin have been considered to be the most diverse and abundant group due to the presence of unique ecological characteristics of the coast (Thomas, 1971; 1986). A characteristic feature noted by him was the dense growth of sponges in the rocky bottom and associated sand bottom. He reported several new species to science with detailed systematic account and remains as 
a monumental contribution to the spongiology of Gulf of Mannar. Thomas (1979) presented a systematic account of 32 boring sponges belonging to three orders, four families and 13 genera from the coral reefs of the Gulf of Mannar Ecosystem. Since the inception of the Marine Biodiversity Division of the ICAR-Central Marine Fisheries Research Institute, several research programmes were taken up to fill the gaps in the Taxonomy of the important groups of the marine organism. In this context the present exploration and taxonomic work on the diversity, distribution pattern, habitat interactions of the sponges occurring along the coral reef ecosystems, pearl oyster beds and coastal areas was taken up along the Tuticorin coast of the Gulf of Mannar area. It forms the part of the All India Coordinated Project on Taxonomy (AICOPTAX), a new initiative from the Ministry of Environment, Forests and Climate Change, New Delhi to create the data base on the inventories of the faunal diversity of India.

\section{Material and methods}

Sponge samples were collected from Vaippar-Manappad area of the Tuticorin in Gulf of Mannar during the period from September 2018 to May 2019.

\section{Sampling localities}

The following localities (Fig. 1) were selected for sample collection:

Periathalai (8॰18'20.53" N \& 7758'58.80" E): Periathalai is a coastal fishing village situated $53 \mathrm{~km}$ from Thirunalveli. The bottom is sandy nearby the coast, rocky and muddy at a depth of 5-12 m. The Sponge samples landed were from Ovari Anthoniar kovil vallai velai paar pearl oyster bed. Six sponge specimens were collected from the area during the field trip on 21.05.2019 (PR1 - PR6) and preserved.

Manappad ( $\left.8^{\circ} 22^{\prime} 6.36^{\prime \prime} \mathrm{N} \& 78^{\circ} 05^{\prime} 41.09^{\prime \prime} \mathrm{E}\right)$ : Manappad is 60 $\mathrm{km}$ away from Tuticorin and is a fishing village of ancient history. The rocky shore of Manapad inhabitate high biodiversity and abundant growth of sponges. A total of 11 sponge samples were collected from Manappad periya paar Pearl Oyster bed on 21.05.2019 (MP1 - MP11) and preserved.

Kulasekharapatnam $\left(8^{\circ} 24^{\prime} 33.31^{\prime \prime} \mathrm{N} \& 78^{\circ} 04^{\prime} 30.61^{\prime \prime} \mathrm{E}\right)$ : Kulasekharapatnam is an ancient port and now serves as a fish landing centre. The bottom is sandy but near shore is rocky with a depth range of 5-12 m. The Sponge samples landed were from Paracherry paar pearl oyster bed. A total of 11 sponge samples were collected on 21.05.2019 (KU1 - KU11) and preserved.

Alanthalai $\left(8^{\circ} 28^{\prime} 57.75^{\prime \prime} \mathrm{N} \& 78^{\circ} 8^{\prime} 21.71^{\prime \prime} \mathrm{E}\right)$ : Alanthalai is 4 $\mathrm{km}$ away from Thiruchandhur and, it is a coastal fishing village.
In ancient times Alanthalai was famous for pearl fishery. Two pearl oyster beds Semma pathu paar and Alanthalai pathoor at a depth of $8 \mathrm{~m}$ form a suitable habitat for sponges. A total of 11 sponge specimens were collected from the area during field trips on 01.12.2018 (AL1 - AL7) and 21.05.2019 (AL8 AL11) and analysed.

Veerapandiyapatnam (8॰31'17.22" N \& 788'29.27" E): Veerapandiyapatnam is a coastal village near Thiruchandhur and an important fish landing center. The bottom is sandy and muddy and support sponge fauna. The sponge samples collected were from Thundu paar pearl oyster bed. Seven sponge samples were collected from the area during field trip on 20.05.2019 (VE1 - VE7) and analysed.

Kayalpatnam (8॰34'27.36" N \& 78 9'15.81" E): Kayalpatnam is an ancient town which was referred in Marco Polo's travel diaries dating to $1250 \mathrm{~A} \mathrm{D}$. It is $30 \mathrm{~km}$ away from Tuticorin and was an ancient port. The bottom is rocky, sandy and muddy. Three pearl oyster beds (paars) support the heavy growth of sponges in this area. The gill nets and modified gill nets operating here, bring considerable quantity of mollusks and sponges as by-catch. The sponges collected from this area were from Pearl oyster beds Kilathi paar, Kandiyan paar and Kanawa paar. A total of 39 sponge specimens were collected during field surveys conducted on 01.12.2018 (KP1 - KP9, KPI1 - KPI8, KPII1 - KPII2) and 22.05.2019 (KP10 - KP29) and analysed.

Tuticorin Harbour ( $8^{\circ} 43^{\prime} 4.85$ N \& 78 $\left.18^{\prime} 46.59^{\prime \prime} \mathrm{E}\right)$ : Harbour beach is around $8 \mathrm{~km}$ from Tuticorin town and it serves dual-purpose such as landing of Gill net and shore seine from morning up to 1 p.m. and from 4 p.m. onward beach tourism kicks in at the same place. The sponges collected from this area were caught from Hare coral island and pearl oyster beds such as Thundu Paar, Kanna tivu and Arupagam paar by the gill netters operating at a depth of $5-10 \mathrm{~m}$. A total of 8 sponge samples were collected on 10.09.2018 (HB1- HB7) and 18.05.2019 (HB8), specimens were preserved and analysed.

Hare Island ( $\left.8^{\circ} 47^{\prime} 19.58^{\prime \prime} \mathrm{N} \& 78^{\circ} 14^{\prime} 12.80^{\prime \prime} \mathrm{E}\right)$ : Hare Island is $9 \mathrm{~km}$ away from Tuticorin town and near to the Tuticorin Port. Island is a part of Gulf of Mannar National Park with an area of $1.29 \mathrm{~km}^{2}$. The bottom is sandy with numerous shells and abundant growth of sea grass. Sponge sample was collected from the area on 07.09.2018 it was then labelled (HI1) and preserved.

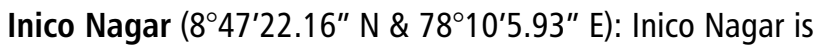
a fish landing center of Tuticorin for gillnetters and disco, they operate at a depth of 5-8 $\mathrm{m}$ in the coral and sandy habitats. The 


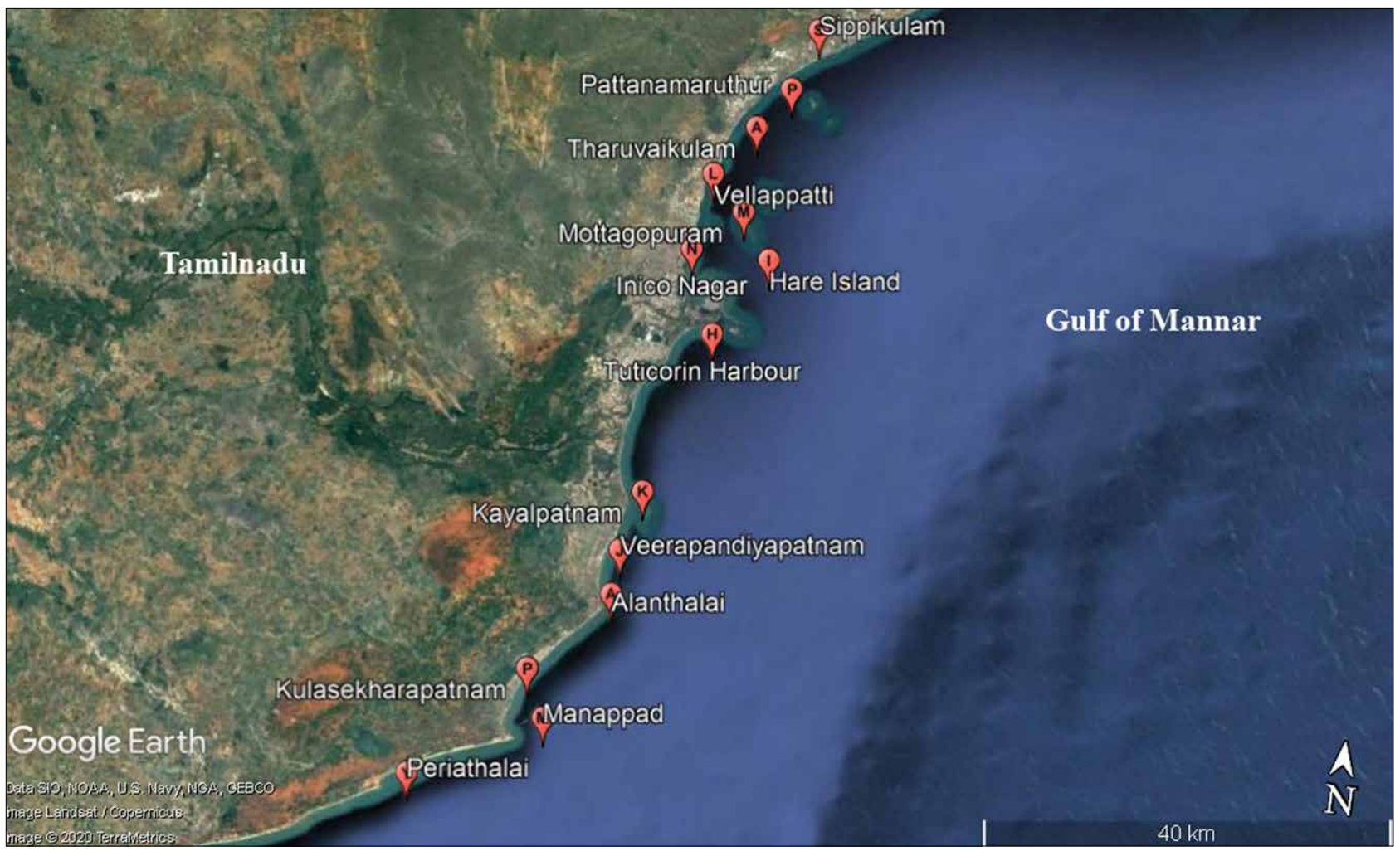

Fig. 1. Sampling stations of the Tuticorin area during 2018-2019.

sponges collected from this area were from Vann Coral Island and Kilathi paar Pearl oyster bed. Four samples of sponges were collected from the location during field survey on 29.11.2018 (IN1 - IN4) and analysed.

Mottagopuram ( $\left.8^{\circ} 49^{\prime} 39.38^{\prime \prime} \mathrm{N} \& 78^{\circ} 12^{\prime} 32.77^{\prime \prime} \mathrm{E}\right)$ : Mottagopuram is located $5 \mathrm{~km}$ away from Tuticorin town and is an ancient fishing village. The special fishing gears Thallumadi (mini trawl) and Karavalai operates in 3- $4 \mathrm{~km}$ from the shore within a depth of $5 \mathrm{~m}$. The sea grass beds nearby the coral Island and the rocky habitat of pearl oyster beds forms a very good ecosystem for sponges. The sponge samples collected from the area were from Vann coral Island and Paduthamarikan thundu paar pearl oyster bed. A total of 30 sponge samples were collected from the locations and preserved during field surveys on 14.09.2018 (MG1- MG5) and 20.05.2019 (MG6 - MG30) and analysed.

Vellappatti ( $8^{\circ} 51^{\prime} 25.46^{\prime \prime} \mathrm{N} \& 78^{\circ} 10^{\prime} 40.86^{\prime \prime}$ E): Vellappatti is a traditional fishing village, which is about $35 \mathrm{~km}$ away from Tuticorin. The coastal area nearby Vellapatti is mainly rocky and sandy bottom with the presence of varieties of sponges. Fishing takes place mainly outside the reef areas. Crab net and Mayavalai for perches bring sponges and mollusks as a by-catch. The sponges collected from this area were mainly from Koswari coral Island and Vann Island along with Pearl oyster bed in Tuticorin kuda paar. A total of 72 sponge specimens were collected during field surveys conducted on 28.11.2018 (VP1 - VP13) and 20.05.2019 (VP14- VP72) and analysed.

Tharuvaikulam $\left(8^{\circ} 54^{\prime} 8.98^{\prime \prime} \mathrm{N} \& 78^{\circ} 12^{\prime} 37.33^{\prime \prime} \mathrm{E}\right)$ : Tharuvaikulam is a small fishing village practicing gill net fisheries, located $10 \mathrm{~km}$ away from Tuticorin. The sponges collected from this area were mainly from Koswari coral Island and Pearl oyster beds of Cruxian paar and Devi paar. Sponges occur at a depth range of 8-12 m. Modified gill nets of different types lands sponges and mollusks as by-catch. Five sponge specimens were collected and preserved from the area during field survey on 14.09.2018 (TK1 - TK5).

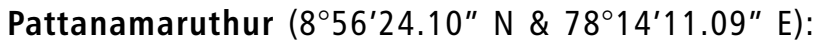
Pattanamaruthur is a village panchayat located in the Tuticorin district of Tamil-Nadu. It is located $24 \mathrm{~km}$ away from Tuticorin. The sampling area consisted of two coral islands Kariyachalli and Koswari with rocky and sandy bottom with rich sea grass bed and Pearl Oyster bed Devi paar which provides optimum conditions for sponge growth. The area of fishing is up to 15 $\mathrm{km}$ from the shore mainly outside the islands. The gill nets and crab nets bring sponges and molluscs as bycatch. A total of 17 sponge specimens were collected during field surveys conducted on 20.05.2019 (PT1 - PT17) and preserved. 


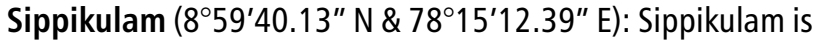
$40 \mathrm{~km}$ away from Tuticorin where the Vaipaar River joins the Bay of Bengal. The bottom is mainly sandy with the presence of abundant molluscan fauna. The samples collected were from Kariyachalli coral island and Paduthamarikan thundu paar pearl oyster bed which forms good habitat for sponges at a depth of $12 \mathrm{~m}$. A total of 9 sponge specimens were collected from the area during field trip on 20.05.2019 (SP1 - SP9) and analysed.

\section{Collection and identification}

Sponges were collected by handpicking, snorkeling and SCUBA diving at various localities at a depth of 0-50 m. Visual observation of the sponge species was done and in situ photographs were taken. The collected samples were brought to the laboratory and preserved. During September 2018 and May 2019, a total of 231 sponge samples were collected from the shore as well as Sea. The sponges entangled in gill nets were also collected and preserved. The sponges were identified as per the detailed diagnostic characters given in past literature (Lendenfeld, 1889; Bergquist, 1980; Cook and Bergquist, 2002; Hooper and Van Soest, 2002). Details of the distribution and systematic status of sponges were referred from the World Porifera Database (Van Soest et al., 2020). A checklist of sponges reported from Tuticorin area was prepared and presented.

\section{Results and discussion}

\section{Checklist of species}

A list of 114 species of sponges was consolidated during the study from the present collection and past records (Table 1). The checklist comprises 113 species of siliceous (Class Demospongia) and one calcareous (Class Calcarea) sponge representing 65 genera, 37 families and 16 orders. During the documentation of the list, review of the old names and several systematics and nomenclature modifications of the past names were done to get a uniform checklist of the species. The past studies along the Tuticorin coast revealed the presence of about 94 species along the coast (Dendy, 1905; Hornell, 1905; Nayar and Mahadevan, 1964, 1987; Mahadevan and Nayar, 1967, 1974; Thomas, 1986; Anita and Lazarus, 2006). The list includes 18 new records from the Tuticorin coast of Gulf of Mannar. The new records are Aiolochoria crassa, Axinella damicornis, Clathria (Clathria) prolifera, Clathrina sororcula, Clathrina sinusarabica, Clathrina coriacea, Cliona delitrix, Colospongia auris, Crella incrustans, Crambe crambe, Hyattella pertusa, Plakortis simplex, Petrosia (Petrosia) ficiformis, Phorbas plumosus, Spheciospongia vesparium, Spirastrella cunctatrix, Sycon ciliatum and Xestospongia muta (Table 1). Family wise list and other details of new records of species observed during the present study are given below.

\section{Family Aplysinidae Carter, 1875}

\section{Aiolochroia crassa (Hyatt, 1875)}

(Plate I, Fig.1)

Systematics

Class: Demospongiae Sollas, 1885

Order: Verongiida Bergquist, 1978

Family: Aplysinidae Carter, 1875a

Genus: Aiolochroia Wiedenmayer, 1977

Species: Aiolochroia crassa (Hyatt, 1875)

Type species: Dendrospongia crassa: Hyatt, 1875: 401, pl.13 [Memoirs of the Boston Society of Natural History. 2] Bahamian, Atlantic. Valid as Aiolochroia crassa (Hyatt, 1875).

Description: Massive to lobate, presence of a knob shaped conules. The color is light golden yellow with a small mixture of colors in different areas. When taken out of water specimen turns to dark purple and dry specimens are purple black.

Distribution: This species was found in the Pearl oyster paar (rocky bottom) was covered by coral sand of Kayalpatnam. Widely known from Atlantic Ocean (Laubenfels, 1950; Wiedenmayer, 1977; Rützler et al., 2009; Van Soest, 2017), Caribbean Sea (Van Soest, 1978; Zea,1987; Lehnert,1993; Rützler et al., 2000) and Gulf of Mexico (Green, 1977).

Remarks: The species occurs in the Gulf of Mexico and Atlantic Ocean. Laubenfels (1948) recorded its occurrence in the IndoWest Pacific. Most probably the species may be introduced into Gulf of Mannar Ecosystem especially the present locality Kayalpatnam was an ancient port during the $15^{\text {th }}$ century and a lot of fishing activities occurred during that period from Atlantic Ocean. Detailed surveys were undertaken to confirm its occurrence at Kayalpatnam as an alien species.

\section{Family Axinellidae Carter, 1875}

\section{Axinella damicornis (Esper, 1794)}

(Plate I, Fig. 2)

Systematics

Class: Demospongiae Sollas, 1885

Order: Axinellida Lévi, 1953

Family: Axinellidae Carter, 1875

Genus: Axinella Schmidt, 1862 (Genus)

Species: Axinella damicornis (Esper, 1794)

Type species: Spongia damicornis Esper, 1794, Esper, 1794:249, pl. XXIX [Zweyter Theil, Raspe: Nürnberg] locality unclear. Valid as Axinella damicornis (Esper, 1794). 
Description: Branching with branches fused together. Irregular in growth and velvety with dusted blue particles. Live color is orange red. It occurs in the sandy bottom.

Distribution: Axinella damicornis was found in the sandy bed of Kayalpatnam. It occurs in the Atlantic Ocean (Van Soest, 1993) and Mediterranean Sea (Topsent, 1934; Idan et al., 2018).

Remarks: It is a common species in Mediterranean and its appearance at Kayalpatnam may be due to its introduction from Mediterranean Sea through ship transportation.

\section{Family Clathrinidae Minchin, 1900}

\section{Clathrina sororcula Van Soest \& De Voogd, 2015}

(Plate I, Fig. 3)

Systematics

Class: Calcarea Bowerbank, 1862
Order: Clathrinida Hartman, 1958

Family: Clathrinidae Minchin, 1900

Genus: Clathrina Gray, 1867

Species: Clathrina sororcula Van Soest \& De Voogd, 2015

Type species: Clathrina sororcula Van Soest \& De Voogd, 2015, 14-15, fig.7 [Zootaxa. 3951(1)] Malacca Strait, Singapore. Valid as Clathrina sororcula Van Soest \& De Voogd, 2015.

Description: Cushion like white, semitransparent tubular body encrusting on rocks. Oscules are visible. Live colouration is white. Presence of sea grass and seaweed along sponge habitat.

Distribution: This species was found in the coral sand area of Kayalpatnam. It occurs in the Pacific Ocean (Van Soest and De Voogd, 2015) and Indian Ocean (Van Soest and De Voogd, 2015).

Remarks: The Holotype locality was Singapore and Paratype from Indonesia. It is a new record with regard to the Gulf of Mannar Ecosystem.
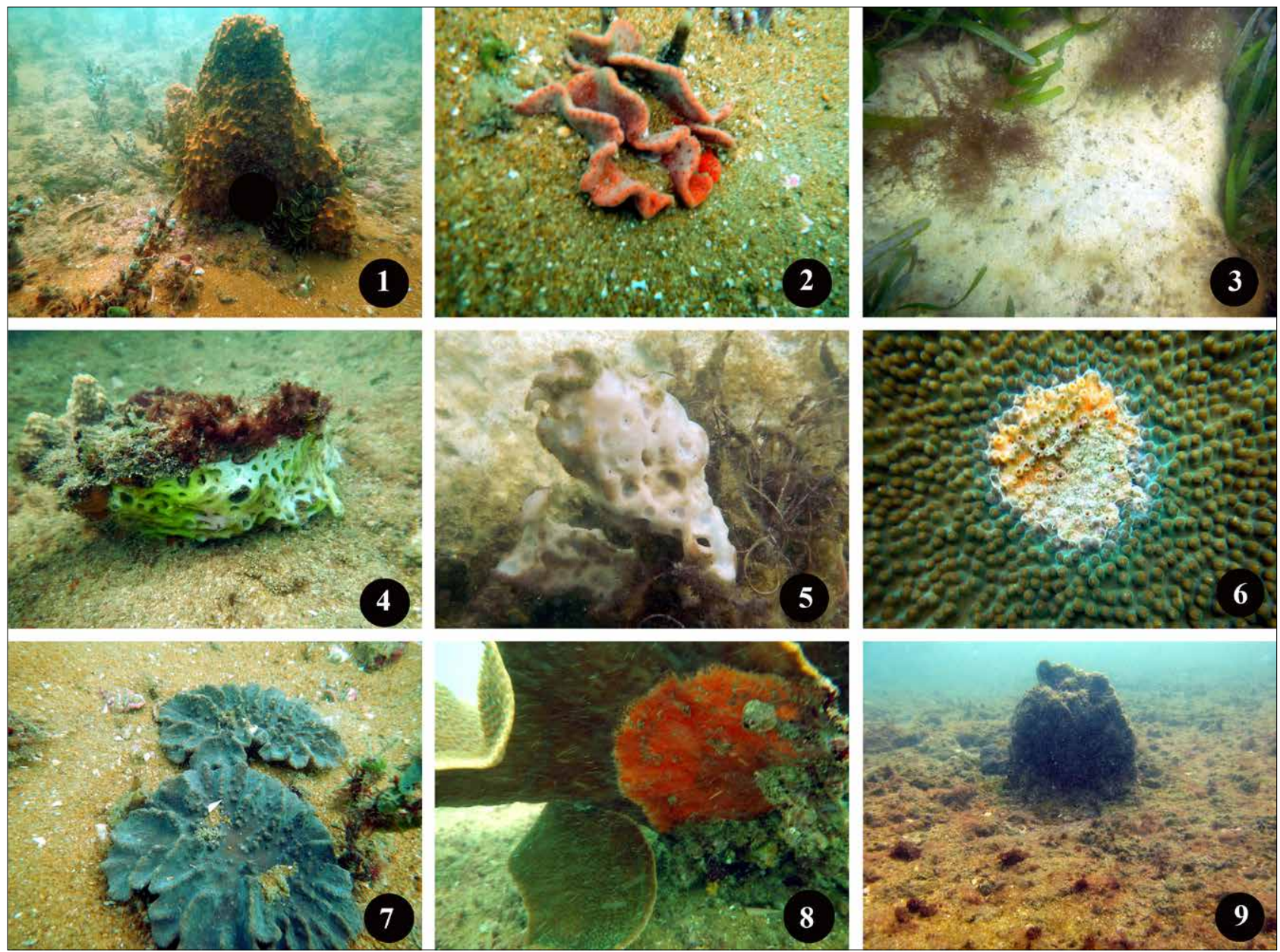

Plate I. New records of sponges from Tuticorin area 1. Aiolochroia crassa 2. Axinella damicornis 3. Clathrina sororcula 4. Clathrina sinusarabica 5. Clathrina coriacea 6. Cliona delitrix 7. Collospongia auris 8. Spirastrella cunctatrix 9. Spheciospongia vesparium (all photographs under water in situ) 


\section{Clathrina sinusarabica Klautau \& Valentine, 2003}

(Plate I, Fig.4)

Systematics

Class: Calcarea Bowerbank, 1862

Order: Clathrinida Hartman, 1958

Family: Clathrinidae Minchin, 1900

Genus: Clathrina Gray, 1867

Species: Clathrina sinusarabica Klautau \& Valentine, 2003

Type species: Clathrina sinusarabica Klautau \& Valentine, 2003,45, fig.37 [Zoological Journal of the Linnean Society. 139(10] Red Sea, Egypt. Valid as Clathrina sinusarabica Klautau \& Valentine, 2003.

Description: Tubular sponge body encrusting a rock and irregular in shape. Color in fresh condition is white.

Distribution: This species was found in the seagrass bed of Kayalpatnam. It occurs in the Red sea (Voigt et al., 2017; Van Soest and De Voogd, 2018) and Indian Ocean (Van Soest and De Voogd, 2018).

Remarks: Clathrina sinusarabica is distributed in the Red sea and occurs at Gulf of Aqaba, Northern and Central Red Sea, Saudi Arabia. This is the first report of from Gulf of Mannar of India.

\section{Clathrina coriacea (Montagu, 1814)}

(Plate I, Fig. 5)

Systematics

Class: Calcarea Bowerbank, 1862

Order: Clathrinida Hartman, 1958

Family: Clathrinidae Minchin, 1900

Genus: Clathrina Gray, 1867

Species: Clathrina coriacea (Montagu, 1814)

Type species: Spongia coriacea Montagu, 1814, 116 [Memoirs of the Wernerian Natural History Society. 2(1)] Celtic Seas. Valid as Clathrina coriacea (Montagu, 1814).

Description: Sponge body is irregular and loosely formed. It was identified by the presence of triactines which are conical and cylindrical in shape.

Distribution: This species was found in the coral reef areas of Kayalpatnam. It occurs in the Mediterranean Sea (Rützler, 1965), Atlantic Ocean (Borojevic, 1967; Wiedenmayer 1977; Rützler 1986), Indian Ocean (Borojevic and Grua, 1965; Thomas, 1979), Pacific Ocean (Ridley, 1881; Kelly et al., 2009), Artic Ocean (Fristedt, 1887; Burton, 1930) and Red sea (Vine, 1986).
Remarks: This species was reported from several parts of Mediterranean and Atlantic Ocean. The present record is the first report from the Gulf of Mannar of India. It does not seem to be cosmopolitan, but a geographically well-defined species from the North Atlantic.

\section{Family Clionaidae d'Orbigny, 1851}

\section{Cliona delitrix Pang, 1973}

(Plate I, Fig. 6)

Systematics

Class: Demospongiae Sollas, 1885

Order: Clionaida Morrow \& Cárdenas, 2015

Family: Clionaidae d'Orbigny, 1851

Genus: Cliona Grant, 1826

Species: Cliona delitrix Pang, 1973

Type species: Cliona delitrix Pang, 1973, 28-31 [Postilla. 161] Greater Antilles. Valid as Cliona delitrix Pang, 1973.

Description: Encrusting on coral and damages coral. The oscules are prominent and relatively large. The spicules consist of tylostyles. Colour in live condition is orange. The outer circumference of the species is blue in colour.

Distribution: This species was a boring sponge found in the cup coral at Kayalpatnam. It occurs in the Caribbean Sea (Buznego and Alcolado, 1987; Pérez et al., 2017) and Atlantic Ocean (Van Soest, 1981).

Remarks: It was reported from Caribbean Sea and Gulf of Mexico. This species also may be introduced to Gulf of Mannar, Ecosystem from other ecosystems. This was the first report of Cliona delitrix from Gulf of Mannar of India.

\section{Family Thorectidae Bergquist, 1978}

\section{Collospongia auris Bergquist, Cambie \& Kernan, 1990}

(Plate I, Fig.7)

Systematics

Class: Demospongiae Sollas, 1885

Order: Dictyoceratida Minchin, 1900

Family: Thorectidae Bergquist, 1978

Genus: Collospongia Bergquist, Cambie \& Kernan, 1990

Species: Collospongia auris Bergquist, Cambie \& Kernan, 1990

Type species: Collospongia auris Bergquist et al, 1990, 350353 [Biochemical Systematics and Ecology. 18 (5):] Great 
Barrier Reef, Australia. Valid as Collospongia auris Bergquist, Cambie \& Kernan, 1990.

Description: Sponge with a thin body and spread on coral reefs. The live color of the sponge is greenish blue sandy with coral and molluscan shells. Surface is smooth with elevating irregularly. Presence of primary and secondary fibers.

Distribution: This species was found in the sandy bottom of Kayalpatnam. It occurs in the Pacific Ocean (Bergquist et al., 1990).

Remark: It was reported from Great Barrier Reefs in Coral Habitat. This is the first report of the speciesfrom the coral ecosystem of Gulf of Mannar, India.

\section{Family Spirastrellidae Ridley \& Dendy, 1886}

\section{Spirastrella cunctatrix Schmidt, 1868}

(Plate I, Fig. 8)

Systematics

Class: Demospongiae Sollas, 1885

Order: Clionaida Morrow \& Cárdenas, 2015

Family: Spirastrellidae Ridley \& Dendy, 1886

Genus: Spirastrella Schmidt, 1868

Species: Spirastrella cunctatrix Schmidt, 1868

Type species: Spirastrella cunctatrix Schmidt, 1868, 17, pl.III 8 [Drittes Supplement, Wilhelm Engelmann: Leipzig: i-iv] Carribbean. Valid as Spirastrella cunctatrix Schmidt, 1868.

Description: Encrusting sponge which occurs in the coral area. Tylostyles and spirasters are present in the skeleton. Live colouration is orange. It is usually attached to cup coral.

Distribution: This species was found in the coral plates of Kayalpatnam. It occurs in the Mediterranean Sea (Lévi, 1957; Rützler, 1965; BouryEsnault, 1971), Atlantic Ocean (Lévi, 1959; Logan et al., 1984; Van Soest, 2001), Indian Ocean (Hentschel, 1909; Vacelet and Vasseur, 1971), Caribbean Sea (Laubenfels, 1936) Pacific Ocean (DesqueyrouxFaúndez, 1990) and Red sea (Lévi, 1965).

Remarks: It was reported from different localities like Mediterranean, West Indies and Atlantic. This is the first report of sponge from Gulf of Mannar, India.

\section{Spheciospongia vesparium (Lamarck, 1815)}

(Plate I, Fig. 9)

Systematics

Class: Demospongiae Sollas, 1885

Order: Clionaida Morrow \& Cárdenas, 2015
Family: Clionaidae d'Orbigny, 1851

Genus: Spheciospongia Marshall, 1892

Species: Spheciospongia vesparium (Lamarck, 1815)

Type species: Alcyonium vesparium Lamarck, 1815, 69-89 [Mémoires du Muséum d'Histoire naturelle, Paris. 1] Greater Antilles. Valid as Spheciospongia vesparium (Lamarck, 1815).

Description: Sponge body is erect with an apical oscule. It grows to large size. Live color is brown at surface and grey inside.

Distribution: This species was found in the coral sand area of Kayalpatnam. It occurs in the Atlantic Ocean (George and Wilson, 1919; Arndt, 1927; Laubenfels, 1936; Rützler, 1974; Wiedenmayer, 1977) and the Caribbean Sea (Duchassaing de Fonbressin and Michelotti, 1864; Bowerbank, 1872; Hechtel, 1965; Rützler et al., 2014).

Remarks: This species is widely distributed, and this is the first report from Tuticorin area of Gulf of Mannar.

\section{Family Microcionidae Carter, 1875}

\section{Clathria (Clathria) prolifera (Ellis \& Solander, 1786)}

(Plate II, Fig.10)

Systematics

Class: Demospongiae Sollas, 1885

Order: Poecilosclerida Topsent, 1928

Family: Microcionidae Carter, 1875

Genus: Clathria Schmidt, 1862

Sub Genus: Clathria (Clathria) Schmidt, 1862

Species: Clathria (Clathria) prolifera (Ellis \& Solander, 1786)

Type species: Spongia prolifera Ellis \& Solander, 1786, 189190 [Systematically arranged and described by the late Daniel Solander. 4] New Jersey, NW Atlantic. Valid as Clathria (Clathria) prolifera (Ellis \& Solander, 1786).

Description: Encrusting, lamellate and attached to coral rocks and pearl oyster paars. Small, short tubular. The skeleton has subtylostyles, microscleres and toxas. Live color is orange red.

Distribution: This species was found in the sandy area of Kayalpatnam. Occurs in the Atlantic Ocean (Desor, 1848 (1851); Lambe, 1896; George and Wilson, 1919; Johnson, 1971; Van Soest, 1984; Trott, 2004).

Remarks: Originally described from New Jersey, NW Atlantic and subsequently reported from the whole Eastern Seaboard of the USA and south to Florida, Mexico and Brazil. The tropical 
records of this species need to be re-examined and are expected to belong to a different species (van Soest, 1993). This is the first report from Tuticorin area of Gulf of Mannar.

\section{Family Crellidae Dendy, 1922}

\section{Crella incrustans (Carter, 1885)}

(Plate II, Fig.11)

Systematics

Class: Demospongiae Sollas, 1885

Order: Poecilosclerida Topsent, 1928

Family: Crellidae Dendy, 1922

Genus: Crella Gray, 1867

Species: Crella incrustans (Carter, 1885)

Type species: Echinonema incrustans Carter, 1885, 353 [Annals and Magazine of Natural History. (5) 16(94)] Bassian, Port Phillips. Valid as Crella incrustans (Carter, 1885).
Description: Encrusting, massive, smooth, color seems to be red coloured. Compressible and tough. Surface is smooth with dermal membrane. Skeleton containing acanthostyles, oxeas and sigma. Live color is bright red.

Distribution: This species was found in the coral reef area of Kayalpatnam. Occurs in the Pacific Ocean (Kim and Sim, 2001; Kelly et al., 2009; Whitelegge, 1901).

Remarks: The present record is new to Tuticorin area of Gulf of Mannar Ecosystem.

\section{Family Crambeidae Lévi, 1963}

\section{Crambe crambe (Schmidt, 1862)}

(Plate II, Fig.12)

Systematics

Class: Demospongiae Sollas, 1885
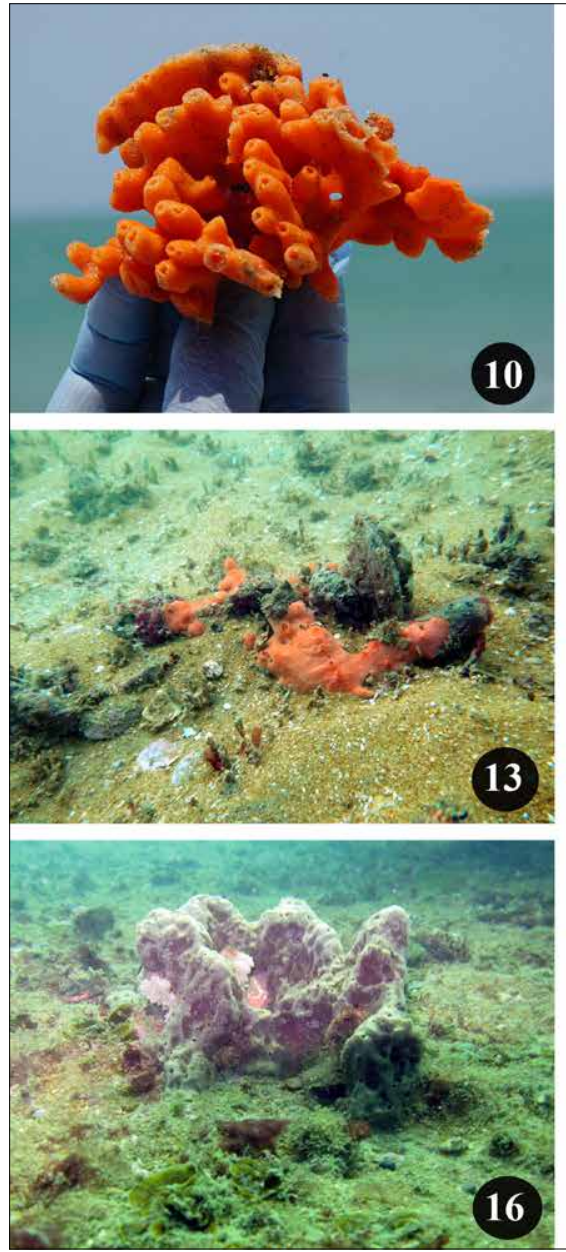

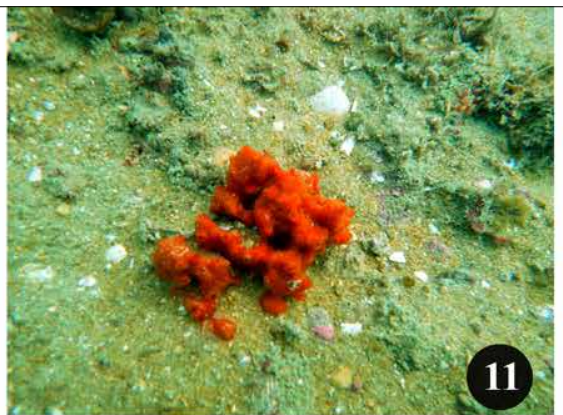

11
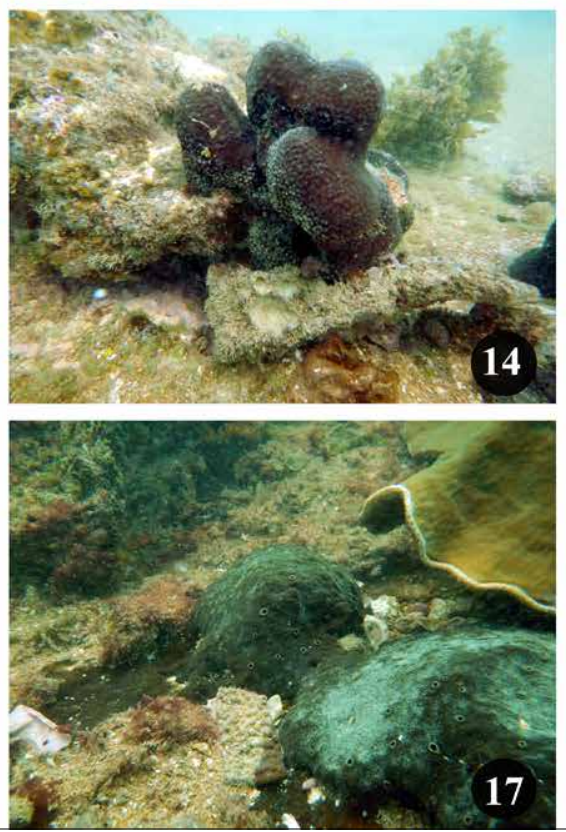
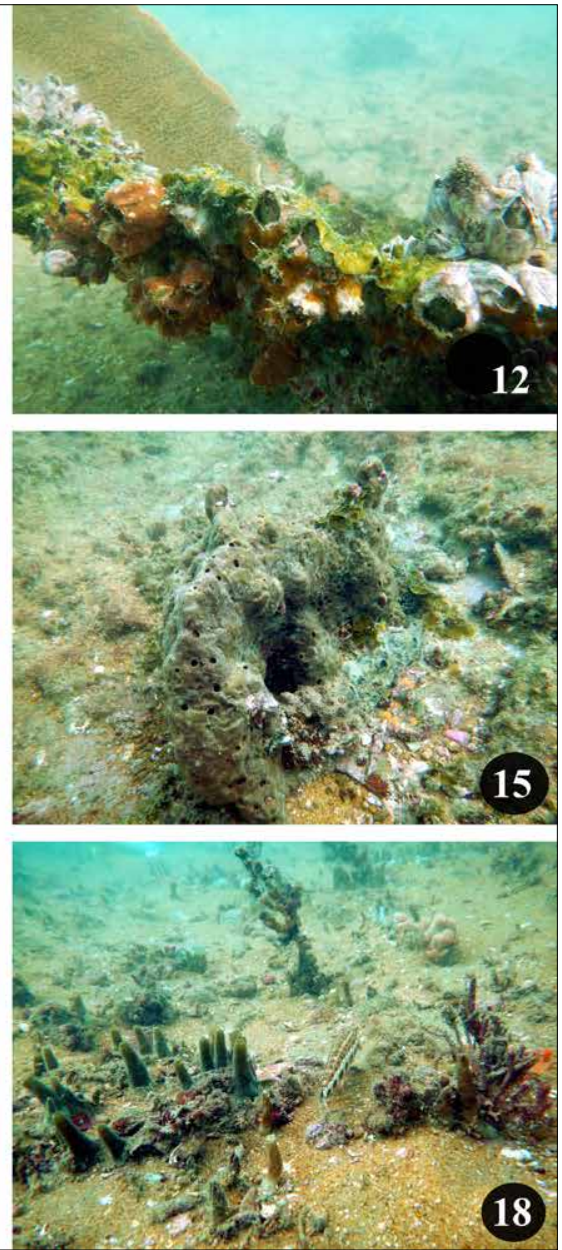

Plate II. New records of sponges from Tuticorin area 10. Clathria (Clathria) prolifera 11. Crella incrustans 12. Crambe crambe 13. Phorbas plumosus 14. Hyattella pertusa 15. Petrosia (Petrosia) ficiformis 16. Xestospongia muta 17. Plakortis simplex 18. Sycon ciliatum (all photographs under water in situ except 10) 
Order: Poecilosclerida Topsent, 1928

Family: Crambeidae Lévi, 1963

Genus: Crambe Vosmaer, 1880

Species: Crambe crambe (Schmidt, 1862)

Type species: Suberites crambe Schmidt, 1862, 1-88, pl.1-7 [Die Spongien des adriatischen Meeres Wilhelm Engelmann: Leipzig: i-viii] Adriatic Sea. Valid as Crambe crambe (Schmidt, 1862)

Description: Encrusting, massive, tubular growth form flat crust. Surface translucent. Live colouration is light orange.

Distribution: This species was found attached to cup coral and dead molluscan shells in the coral reef area of Kayalpatnam. Occurs in the Mediterranean Sea (Schmidt, 1862; Topsent, 1892; Burton, 1936; Sarà and Siribelli, 1960), Indian Ocean (Barnes and Bell, 2002) and Atlantic Ocean (Van Soest, 2001; Boury-Esnault et al., 2001 [2005]).

Remarks: This is the first report of Crambe crambe from the Gulf of Mannar Ecosystem.

\section{Family Hymedesmiidae Topsent, 1928}

\section{Phorbas plumosus (Montagu, 1814)}

(Plate II, Fig.13)

Systematics

Class: Demospongiae Sollas, 1885

Order: Poecilosclerida Topsent, 1928

Family: Hymedesmiidae Topsent, 1928

Genus: Phorbas Duchassaing \& Michelotti, 1864

Species: Phorbas plumosus (Montagu, 1814)

Type species: Spongia plumosa Montagu, 1814, 116 [Memoirs of the Wernerian Natural History Society. 2(1)] Celtic Seas. Valid as Phorbas plumosus (Montagu, 1814).

Description: Thickly encrusting, massive, aereolate surface. Live coloration is red.

Distribution: This species was found in the coral reef area of Kayalpatnam. It occurs in the Mediterranean Sea (Topsent, 1892; Sarà, 1961; Evcen and Çinar, 2012), Atlantic Ocean (Montagu, 1814; Bowerbank, 1867; Stephens, 1912; BouryEsnault and Lopes, 1985; Van Soest, 2001) and the Indian Ocean (Carter, 1881).

Remarks: This is the first report of Phorbas plumosus from Gulf of Mannar.

\section{Family Spongiidae Gray, 1867}

\section{Hyattella pertusa (Esper, 1794)}

(Plate II, Fig.14)

Systematics

Class: Demospongiae Sollas, 1885

Order: Dictyoceratida Minchin, 1900

Family Spongiidae Gray, 1867

Genus: Hyattella Lendenfeld, 1888

Species: Hyattella pertusa (Esper, 1794)

Type species: Spongia pertusa Esper, 1794, [Zweyter Theil Raspe: Nürnberg 1-303] India. Valid as Hyattella pertusa (Esper, 1794).

Description: Solid, cup shaped massive sponge body. Several lobes present in the body. The upper surface more or less flattened. Very dense and smooth. Skeleton composed of primary fibers and secondary fibers. Live colouration is dark brown.

Distribution: This species was found in the coral reef area of Kayalpatnam. It occurs in the Indian Ocean (Esper, 1794; Hooper and Van Soest, 2002).

Remarks: This is the first report from the Gulf of Mannar Ecosystem.

\section{Family Petrosiidae van Soest, 1980}

\section{Petrosia (Petrosia) ficiformis (Poiret, 1789)}

(Plate II, Fig. 15)

Systematics

Class: Demospongiae Sollas, 1885

Order: Haplosclerida Topsent, 1928

Family: Petrosiidae van Soest, 1980

Genus: Petrosia Vosmaer, 1885

Sub Genus: Petrosia (Petrosia) Vosmaer, 1885

Species: Petrosia (Petrosia) ficiformis (Esper, 1794)

Spongia ficiformis Poiret, 1789: 55-63 [l'Histoire naturelle de ce Pays. Deuxième Partie Années 1785 et 1786] Western Mediterranean. Valid as Petrosia (Petrosia) ficiformis (Esper, 1794).

Description: Massive sponge, irregularly globular with a wide base, several fused lobes.

Distribution: This species was found in the coral reef area of Kayal patnam. It occurs in the Mediterranean Sea (Poiret, 1789; Schmidt, 1864; Topsent1928; Lévi, 1957) and Atlantic Ocean (Topsent, 1928; Burton, 1956; Lévi and Vacelet, 1958; Van Soest, 2001). 
Remarks: Basically, Petrosia ficiformis occur in the Mediterranean and Atlantic Ocean. May be this species is also introduced to Gulf of Mannar ecosystem through shipping and transport.

\section{Xestospongia muta (Schmidt, 1870)}

(Plate II, Fig.16)

Systematics

Class: Demospongiae Sollas, 1885

Order: Haplosclerida Topsent, 1928

Family: Petrosiidae van Soest, 1980

Genus: Xestospongia Laubenfels, 1932

Species: Xestospongia muta (Schmidt, 1870)

Type species: Schmidtia muta Schmidt, 1870, 44-45 [Gebietes Wilhelm Engelmann: Leipzig iii-iv] Floridian. Valid as Xestospongia muta (Schmidt, 1870).

Description:Discoid body, surface tuberculate, massive or encrusting.

Distribution: This species was found in the coral reef area of Kayalpatnam. It occurs in the Atlantic Ocean (Schmidt, 1870; Laubenfels, 1953; Wiedenmayer, 1977; Hajdu and Fernandez et al., 2011; Van Soest, 2017) and Caribbean Sea (Alcolado, 1976; Van Soest, 1980; Zea, 1987; Rützler et al., 2000; Alcolado and Busutil, 2012; Pérez et al., 2017).

Remarks: This species belongs to Barrel sponge group. Among this group two other species, Xestospongia testudinaria and Petrosia ficiformis were already reported from India. The Xestospongia muta is a new record from Gulf of Mannar.

\section{Family Plakinidae Schulze, 1880}

\section{Plakortis simplex Schulze, 1880}

(Plate II, Fig.17)

Systematics

Class: Homoscleromorpha Bergquist, 1978

Order: Homosclerophorida Dendy, 1905

Family: Plakinidae Schulze, 1880

Genus: Plakortis Schulze, 1880

Species: Plakortis simplex Schulze, 1880

Type species: Plakortis simplex Schulze, 1880, 430-433 [Zeitschrift für wissenschaftliche Zoologie. 34(2)] Western Mediterranean. Valid as Plakortis simplex Schulze, 1880

Description: Thin to massive, encrusting, brown in colour, surface smooth with ostia.
Distribution: This species was found in the coral reef area of Kayalpatnam. It occurs in the Mediterranean Sea (Schulze, 1880; Topsent, 1934; Lévi, 1952). The Atlantic Ocean (Ferrer Hernández, 1918; Topsent, 1928; Burton, 1930; Borojevic et al., 1968; Boury-Esnault, 1973; Van Soest, 1993) The Pacific Ocean (Topsent, 1897; Laubenfels, 1950), the Indian Ocean (Vacelet et al., 1976; Thomas, 1979,1981).

Remarks: This species is widely distributed, and Thomas reported it from Mozambique Channel and Mahe Island. The present record is new to Tuticorin area of Gulf of Mannar area.

\section{Family Sycettidae Dendy, 1893}

\section{Sycon ciliatum (Fabricius, 1780)}

(Plate II, Fig.18)

Systematics

Class: Calcarea Bowerbank, 1862

Order: Leucosolenida Hartman, 1958

Family: Sycettidae Dendy, 1893

Genus: Sycon Risso, 1827

Species: Sycon ciliatum (Fabricius, 1780)

Type species: Spongia ciliata Fabricius, 1780, 452 pp. Fauna Groenlandica, systematice sistens animalia groenlandiae occidentalis hactenus indagata, quoad nomen specificium, triviale, vernaculumque, synonyma auctorum plurimum, descriptionem, locum, victum, generationem, mores, usum capturamque singuli, pro ut detegendi occasio fuit, maximaque parte secundum proprias observations] East Greenland. Valid as Sycon ciliatum (Fabricius, 1780)

Description: Tubular usually single, smooth, soft, papillate and having single terminal oscula which is fringed with a crown of spicules. They are attached to hard substrate like coral reefs/ rocks, surface smooth. Color pale white.

Distribution: This species was found in the coral reef area of Kayalpatnam. It occurs in the Mediterranean Sea (Ellis and Solander, 1786; Schmidt, 1862; Haeckel,1872; Burton, 1936; Topsent and Olivier, 1943), Atlantic Ocean (Fabricius, 1780; Topsent, 1891; Burton, 1933; Borojevic, 1967; Tendal, 1970; Rützler, 1986; Van Soest, 2001), Pacific Ocean (Kelly et al., 2009), Artic Ocean (Haeckel,1872; Arnesen, 1900; Burton, 1930) and Indian Ocean (Trott, 2004; Van Soest and Voogd, 2018).

Remarks: The present record is an extension of the distribution of Sycon ciliatum to the Tuticorin area of Gulf of Mannar. 


\section{Common species}

A total of 17 species of sponges was found to be the most common and abundant from the Hare Island, Tuticorin Harbour Beach, Tharuvaikulam, Mottagopuram, Vellapatti, Inico Nagar, Kayalpatnam, Pattanamaruthur, Sippikulam, Veerapandiyapatnam, Kulasekharapatnam, Alanthalai, Manappad and Periathalai locations. They are Spongionella nigra, Clathria (Clathria) indica, Aulospongus tubulatus, Callyspongia (Euplacella) communis, Axinella donnani (Plate III, Fig.3), Amphimedon subcylindrica, Stylissa carteri, Iotrochota purpurea, Mycale (Mycale) grandis, Mycale (Zygomycale) parishii, Dysidea incrustata, Hyattella intestinalis, Ircinia fusca, Phyllospongia lamellose, Pione margaritiferae, Hemimycale columella (Plate III, Fig.6) and Fasciospongia anomala (Plate III, Fig.5).

\section{Invasive sponges}

Species invasion is a universal phenomenon throughout the world and sponges are no exception to it. The major factors influence the sponge invasion are the ship transportation, ballast water, attachment and biofouling in ships and other vessels, transportation through major ocean canals like Suez Canal and Panama Canal and human activities helps in the successful colonization of invasive species into new environments. In the present study five species of new records of sponges' can be considered as new introduction to the Kayalpatanam area from other places through ship transport. The probable invasive species to this area are Aiolochroia crassa, Clathrina sororcula, Cliona delitrix, Crella incrustans and Crambe crambe. There are similar reports of the sponge about the sponge invasion around the world. Sponge invasions were reported in localities of Dutch coastal waters (Van Soest et al., 2007), Atlantic Ocean (Daniela and Janussen, 2011), Mediterranean Sea (Longo et al., 2007) and Gulf of Morbihan (Perez et al., 2006).

\section{Massive sponges}

The characteristic feature of the Tuticorin coast is the presence and abundance of massive barrel sponges of different size groups. The most abundant species are Xestospongia testudinaria (Lamarck, 1815) (= Pertosia testudinaria) followed by Neopetrosia similis (Ridley \& Dendy, 1886) in the rocky bottom of 10-23 m depth zone. Besides this the Aiolochroia crassa, Spheciospongia inconstans (Hyatt, 1875), lotrochota purpurea (Bowerbank, 1875) are also observed in Tuticorin coast. The past studies along the different pearl oyster beds revealed the abundance of the two species along the coast (Dendy, 1905; Hornell, 1905; Nayar and Mahadevan, 1964, 1987; Mahadevan and Nayar, 1967, 1974; Thomas, 1986). Moreover, the underwater survey conducted in Kayalpatnam area provided information about the loss of biodiversity of sponges in that area as compared to the previous works. The major reasons behind the decline of the number of large species may be attributed to the continuous disturbance of the bottom habitat by navigation of boats and other anthropogenic activities. Another important observation is the decline in the visual spotting of the barrel sponge (Xestospongia testudinaria, Xestospongia muta) which was very abundant during 1889 and 1976 periods at Kayalpatnam paars. It is a great concern to the ecology of the sponge beds
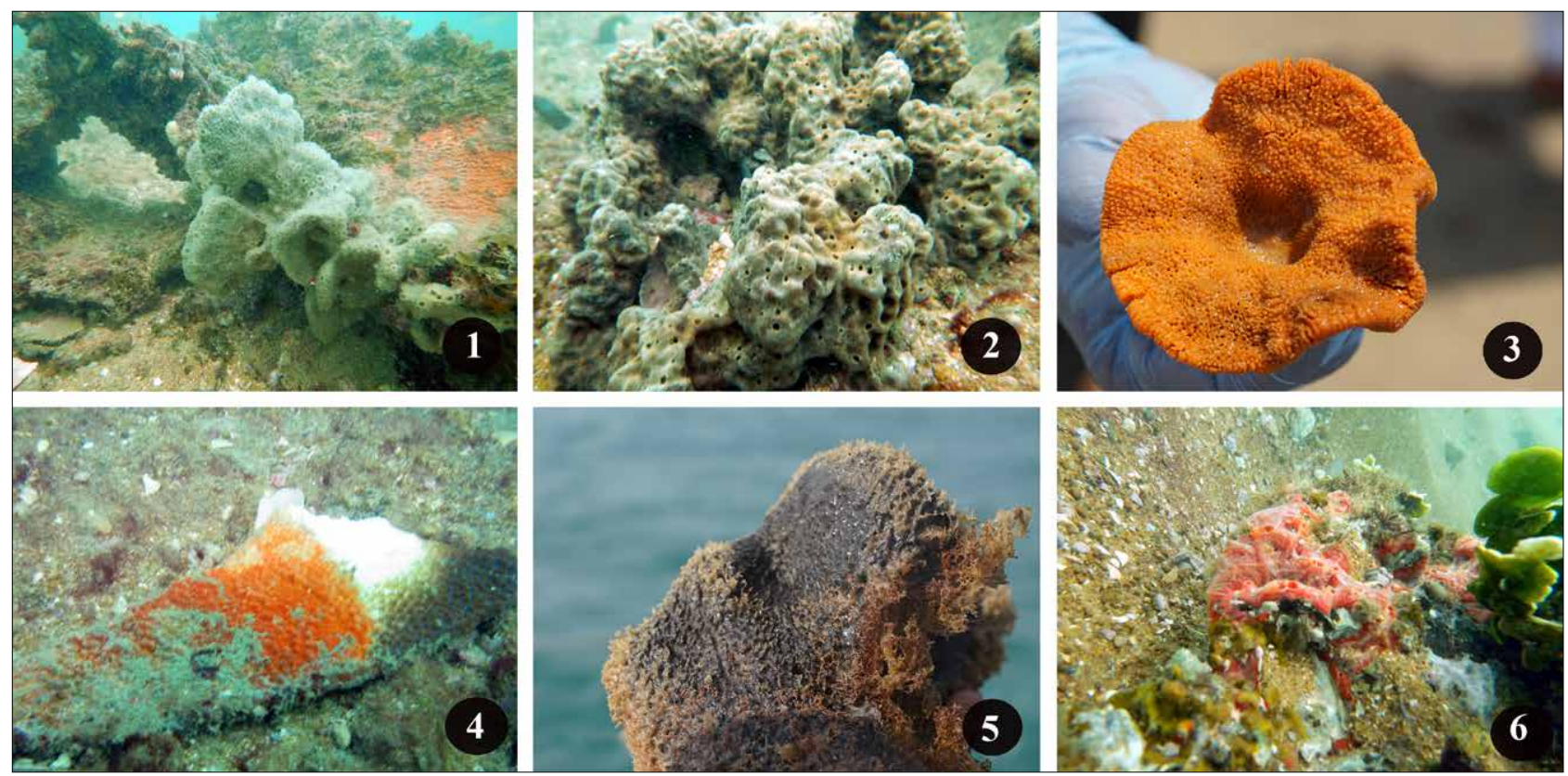

Plate III. Sponge fauna of Tuticorin area 1. Spirastrella coccinea 2. Amorphinopsis excavans 3. Axinella donnani 4. Cliona celata 5. Fasciospongia anomala 6. Hemimycale columella (all photographs under water in situ except 3 and 5) 
Table 1. Check list of sponges occurring in the Tuticorin area

\begin{tabular}{|c|c|c|c|c|}
\hline No & Order & Family & Species name & Reference \\
\hline 1 & Poecilosclerida & Acarnidae & Acarnus ternatus Ridley, 1884 & Dendy, 1905; Thomas, 1986* \\
\hline 2 & Verongiida & Aplysinidae & Aiolochroia crassa (Hyatt, 1875) & New record, Present study \\
\hline 3 & Suberitida & Halichondriidae & Amorphinopsis excavans Carter, 1887 & Thomas, 1986 \\
\hline 4 & Suberitida & Halichondriidae & Amorphinopsis foetida (Dendy, 1889) & Dendy, 1905 \\
\hline 5 & Haplosclerida & Niphatidae & Amphimedon brevispiculifera (Dendy, 1905) & Dendy, 1905 \\
\hline 6 & Haplosclerida & Niphatidae & Amphimedon delicatula (Dendy, 1889) & Dendy, 1905 \\
\hline 7 & Haplosclerida & Niphatidae & Amphimedon subcylindrica (Dendy, 1905) & Mahadevan \& Nayar, 1967† \\
\hline 8 & Poecilosclerida & Microcionidae & Antho (Plocamia) manaarensis (Carter, 1880) & Dendy, 1905; Anita \& Lazarus, 2006 \\
\hline 9 & Tetractinellida & Ancorinidae & Asteropus haeckeli Dendy, 1905 & Dendy, 1905 \\
\hline 10 & Axinellida & Axinellidae & Auletta elongata Dendy, 1905 & Dendy, 1905 \\
\hline 11 & Axinellida & Axinellidae & Auletta lyrata (Esper, 1794) & Dendy, 1905 \\
\hline 12 & Axinellida & Raspailiidae & Aulospongus tubulatus (Bowerbank, 1873) & Dendy, 1905; Mahadevan \& Nayar, 1967 \\
\hline 13 & Axinellida & Axinellidae & Axinella donnani (Bowerbank, 1873) & Dendy, 1905 \\
\hline 14 & Axinellida & Axinellidae & Axinella damicornis (Esper, 1794) & New record, Present study \\
\hline 15 & Axinellida & Axinellidae & Axinella halichondrioides Dendy, 1905 & Dendy, 1905 \\
\hline 16 & Axinellida & Axinellidae & Axinella labyrinthica Dendy, 1889 & Dendy, 1905 \\
\hline 17 & Axinellida & Axinellidae & Axinella manus Dendy, 1905 & Dendy, 1905 \\
\hline 18 & Biemnida & Biemnidae & Biemna tubulata (Dendy, 1905) & Dendy, 1905; Thomas, 1986 \\
\hline 19 & Haplosclerida & Callyspongiidae & Callyspongia (Callyspongia) nuda (Ridley, 1884) & Dendy, 1905 \\
\hline 20 & Haplosclerida & Callyspongiidae & Callyspongia (Callyspongia) reticutis (Dendy, 1905) & Dendy, 1905 \\
\hline 21 & Haplosclerida & Callyspongiidae & Callyspongia (Cladochalina) diffusa (Ridley, 1884) & Dendy, 1905 \\
\hline 22 & Haplosclerida & Callyspongiidae & Callyspongia (Cladochalina) spinilamella (Dendy, 1889) & Dendy, 1905 \\
\hline 23 & Haplosclerida & Callyspongiidae & Callyspongia (Cladochalina) subarmigera (Ridley, 1884) & Dendy, 1905 \\
\hline 24 & Haplosclerida & Callyspongiidae & Callyspongia (Euplacella) communis (Carter, 1881) & Dendy, 1905; Mahadevan \& Nayar, 1967 \\
\hline 25 & Haplosclerida & Callyspongiidae & Callyspongia (Toxochalina) ridleyi (Dendy, 1905) & Dendy, 1905 \\
\hline 26 & Haplosclerida & Callyspongiidae & Callyspongia (Toxochalina) robusta (Ridley, 1884) & Dendy, 1905 \\
\hline 27 & Haplosclerida & Callyspongiidae & Callyspongia clathrata (Dendy, 1905) & Dendy, 1905 \\
\hline 28 & Clionaida & Clionaidae & Cervicornia cuspidifera (Lamarck, 1815) & Thomas, 1986 \\
\hline 29 & Tetractinellida & Tetillidae & Cinachyrella hirsuta (Dendy, 1889) & Dendy, 1905 \\
\hline 30 & Suberitida & Halichondriidae & Ciocalypta digitata (Dendy, 1905) & Dendy, 1905 \\
\hline 31 & Poecilosclerida & Microcionidae & Clathria (Clathria) prolifera (Ellis \& Solander, 1786) & New record, Present study \\
\hline 32 & Clathrinida & Clathrinidae & Clathrina sororcula Van Soest \& De Voogd, 2015 & New record, Present study \\
\hline 33 & Clathrinida & Clathrinidae & Clathrina sinusarabica Klautau \& Valentine, 2003 & New record, Present study \\
\hline 34 & Clathrinida & Clathrinidae & Clathrina coriacea (Montagu, 1814) & New record, Present study \\
\hline 35 & Poecilosclerida & Microcionidae & Clathria (Clathria) indica Dendy, 1889 & Dendy, 1905 Mahadevan \& Nayar, 1967 \\
\hline 36 & Poecilosclerida & Microcionidae & Clathria (Thalysias) procera (Ridley, 1884) & Dendy, 1905 Mahadevan \& Nayar, 1967 \\
\hline 37 & Poecilosclerida & Microcionidae & Clathria (Thalysias) vulpina (Lamarck, 1814) & Dendy, 1905; Anita \& Lazarus, 2006 $\beta$ \\
\hline 38 & Clionaida & Clionaidae & Cliona celata Grant, 1826 & Thomas, 1986 \\
\hline 39 & Clionaida & Clionaidae & Cliona orientalis Thiele, 1900 & Thomas, 1986 \\
\hline
\end{tabular}




\begin{tabular}{|c|c|c|c|c|}
\hline No & Order & Family & Species name & Reference \\
\hline 40 & Clionaida & Clionaidae & Cliona delitrix Pang, 1973 & New record, Present study \\
\hline 41 & Clionaida & Clionaidae & Cliothosa aurivillii (Lindgren, 1897) & Thomas, 1986 \\
\hline 42 & Dictyoceratida & Thorectidae & Collospongia auris Bergquist, Cambie \& Kernan, 1990 & New record, Present study \\
\hline 43 & Poecilosclerida & Crellidae & Crella incrustans (Carter, 1885) & New record, Present study \\
\hline 44 & Poecilosclerida & Crambeidae & Crambe crambe (Schmidt, 1862) & New record, Present study \\
\hline 45 & Tetractinellida & Tetillidae & Craniella elegans Dendy, 1905 & Dendy, 1905 \\
\hline 46 & Clionaida & Clionaidae & Dotona pulchella Carter, 1880 & Thomas, 1986 \\
\hline 47 & Dictyoceratida & Dysideidae & Dysidea incrustata (Dendy, 1905) & Dendy, 1905 \\
\hline 48 & Dictyoceratida & Dysideidae & Dysidea pallescens (Schmidt, 1862) & Dendy, 1905 \\
\hline 49 & Axinellida & Raspailiidae & Echinodictyum clathratum Dendy, 1905 & Sivaleela, 2014 \\
\hline 50 & Axinellida & Raspailiidae & Echinodictyum flabelliforme (Keller, 1889) & Dendy, 1905 \\
\hline 51 & Tetractinellida & Ancorinidae & Ecionemia acervus Bowerbank, 1862 & Dendy, 1905 \\
\hline 52 & Axinellida & Raspailiidae & Endectyon (Endectyon) fruticosum (Dendy, 1887) & Dendy, 1905; Thomas, 1986 \\
\hline 53 & Axinellida & Raspailiidae & Endectyon (Endectyon) hornelli (Dendy, 1905) & Dendy, 1905; Mahadevan \& Nayar, 1967 \\
\hline 54 & Axinellida & Raspailiidae & Endectyon (Endectyon) lamellosum Thomas, 1976 & Thomas, 1986 \\
\hline 55 & Dictyoceratida & Thorectidae & Fasciospongia anomala (Dendy, 1905) & Dendy, 1905; Sivaleela,2014 \\
\hline 56 & Haplosclerida & Niphatidae & Gelliodes carnosa Dendy, 1889 & Dendy, 1905; Anita \& Lazarus, 2006 $\beta$ \\
\hline 57 & Haplosclerida & Niphatidae & Gelliodes incrustans Dendy, 1905 & Dendy, 1905; Thomas, 1986 \\
\hline 58 & Tetractinellida & Geodiidae & Geodia areolata Carter, 1880 & Dendy, 1905; Anita \& Lazarus, 2006 \\
\hline 59 & Tetractinellida & Geodiidae & Geodia ramodigitata Carter, 1880 & Dendy, 1905; Thomas, 1986 \\
\hline 60 & Haplosclerida & Chalinidae & Haliclona (Gellius) fibulata (Schmidt, 1862) & Dendy, 1905 \\
\hline 61 & Haplosclerida & Chalinidae & Haliclona (Gellius) cymaeformis (Esper, 1806) & Dendy, 1905 \\
\hline 62 & Poecilosclerida & Hymedesmiidae & Hemimycale columella (Bowerbank, 1874) & Dendy, 1905 \\
\hline 63 & Poecilosclerida & Microcionidae & Holopsamma crassa Carter, 1885 & Dendy, 1905 \\
\hline 64 & Dictyoceratida & Spongiidae & Hyattella cavernosa (Pallas, 1766) & Dendy, 1905 \\
\hline 65 & Dictyoceratida & Spongiidae & Hyattella intestinalis (Lamarck, 1814) & Dendy, 1905; Thomas, 1986 \\
\hline 66 & Dictyoceratida & Spongiidae & Hyattella cribriformis (Hyatt, 1887) & Thomas, 1986 \\
\hline 67 & Dictyoceratida & Spongiidae & Hyattella pertusa (Esper, 1794) & New record, Present study \\
\hline 68 & Poecilosclerida & lotrochotidae & Iotrochota purpurea (Bowerbank, 1875) & Mahadevan \& Nayar, 1967 \\
\hline 69 & Poecilosclerida & lotrochotidae & lotrochota baculifera Ridley, 1884 & Thomas, 1986 \\
\hline 70 & Dictyoceratida & Irciniidae & Ircinia fusca (Carter, 1880) & Dendy, 1905; Thomas, 1986 \\
\hline 71 & Dictyoceratida & Irciniidae & Ircinia ramosa (Keller, 1889) & Thomas, 1986 \\
\hline 72 & Dictyoceratida & Irciniidae & Ircinia schulzei (Dendy, 1905) & Dendy, 1905 \\
\hline 73 & Leucosolenida & Grantiidae & Leucandra donnani Dendy, 1905 & Dendy, 1905 \\
\hline 74 & Tetractinellida & Scleritodermidae & Microscleroderma herdmani (Dendy, 1905) & Dendy, 1905 \\
\hline 75 & Poecilosclerida & Mycalidae & Mycale (Mycale) grandis Gray, 1867 & Mahadevan \& Nayar, 1967; Thomas, 1986 \\
\hline 76 & Poecilosclerida & Mycalidae & Mycale (Mycale) gravelyi Burton, 1937 & Thomas, 1986 \\
\hline 77 & Poecilosclerida & Mycalidae & Mycale (Zygomycale) parishii (Bowerbank, 1875) & Mahadevan \& Nayar, 1967; Thomas, 1986 \\
\hline 78 & Poecilosclerida & Myxillidae & Myxilla (Ectyomyxilla) arenaria Dendy, 1905 & Dendy, 1905; Mahadevan \& Nayar, 1967 \\
\hline
\end{tabular}




\begin{tabular}{|c|c|c|c|c|}
\hline No & Order & Family & Species name & Reference \\
\hline 79 & Haplosclerida & Petrosiidae & Neopetrosia similis (Ridley \& Dendy, 1886) & Dendy, 1905; Mahadevan \& Nayar, 1967 \\
\hline 80 & Haplosclerida & Niphatidae & Niphates obtusispiculifera (Dendy, 1905) & Dendy, 1905 \\
\hline 81 & Haplosclerida & Phloeodictyidae & Oceanapia sagittaria (Sollas, 1902) & Dendy, 1905; Sivaleela,2014 \\
\hline 82 & Haplosclerida & Phloeodictyidae & Oceanapia zoologica (Dendy, 1905) & Dendy, 1905; Thomas, 1986 \\
\hline 83 & Tetractinellida & Tetillidae & Paratetilla bacca (Selenka, 1867) & Dendy, 1905 \\
\hline 84 & Bubarida & Desmanthidae & Petromica (Petromica) massalis Dendy, 1905 & Dendy, 1905 \\
\hline 85 & Axinellida & Axinellidae & Phakellia symmetrica Dendy, 1905 & Dendy, 1905; Mahadevan \& Nayar, 1967 \\
\hline 86 & Homoscleromorpha & Plakinidae & Plakortis simplex Schulze, 1880 & New record, Present study \\
\hline 87 & Dictyoceratida & Thorectidae & Phyllospongia lamellosa (Esper, 1794) & Thomas, 1986 \\
\hline 88 & Dictyoceratida & Thorectidae & Phyllospongia papyracea (Esper, 1806) & Dendy, 1905; Thomas, 1986 \\
\hline 89 & Haplosclerida & Petrosiidae & Petrosia (Petrosia) ficiformis (Poiret, 1789) & New record, Present study \\
\hline 90 & Clionaida & Clionaidae & Pione carpenteri (Hancock, 1867) & Thomas, 1986 \\
\hline 91 & Clionaida & Clionaidae & Pione margaritiferae (Dendy, 1905) & Dendy, 1905; Thomas, 1986 \\
\hline 92 & Clionaida & Clionaidae & Pione vastifica (Hancock, 1849) & Mahadevan \& Nayar, 1967 \\
\hline 93 & Verongiida & Pseudoceratinidae & Pseudoceratina purpurea (Carter, 1880) & Dendy, 1905 \\
\hline 94 & Poecilosclerida & Hymedesmiidae & Phorbas plumosus (Montagu, 1814) & New record, Present study \\
\hline 95 & Dictyoceratida & Thorectidae & Scalarispongia scalaris (Schmidt, 1862) & Dendy, 1905 \\
\hline 96 & Clionaida & Clionaidae & Spheciospongia inconstans (Dendy, 1887) & Mahadevan \& Nayar, 1967 \\
\hline 97 & Clionaida & Clionaidae & Spheciospongia vesparium (Lamarck, 1815) & New record, Present study \\
\hline 98 & Clionaida & Clionaidae & Spheciospongia vagabunda (Ridley, 1884) & Dendy, 1905 \\
\hline 99 & Clionaida & Spirastrellidae & Spirastrella coccinea (Duchassaing \& Michelotti, 1864) & Thomas, 1986 \\
\hline 100 & Clionaida & Spirastrellidae & Spirastrella cunctatrix Schmidt, 1868 & New record, Present study \\
\hline 101 & Dictyoceratida & Spongiidae & Spongia (Spongia) officinalis Linnaeus, 1759 & Thomas, 1986 \\
\hline 102 & Dendroceratida & Dictyodendrillidae & Spongionella nigra Dendy, 1889 & Dendy, 1905; Mahadevan \& Nayar, 1967 \\
\hline 103 & Dendroceratida & Dictyodendrillidae & Spongionella pulvilla (Dendy, 1905) & Dendy, 1905 \\
\hline 104 & Suberitida & Halichondriidae & Spongosorites topsenti Dendy, 1905 & Dendy, 1905 \\
\hline 105 & Tetractinellida & Ancorinidae & Stelletta agg/utinans (Dendy, 1905) & Dendy, 1905 \\
\hline 106 & Tetractinellida & Ancorinidae & Stelletta herdmani Dendy, 1905 & Dendy, 1905 \\
\hline 107 & Tetractinellida & Ancorinidae & Stelletta vestigium Dendy, 1905 & Dendy, 1905 \\
\hline 108 & Scopalinida & Scopalinidae & Stylissa carteri (Dendy, 1889) & Mahadevan \& Nayar, 1967; Anita \& Lazarus, 2006ß \\
\hline 109 & Leucosolenida & Sycettidae & Sycon ciliatum (Fabricius, 1780) & New record, Present study \\
\hline 110 & Suberitida & Suberitidae & Terpios cruciatus (Dendy, 1905) & Dendy, 1905 \\
\hline 111 & Tethyida & Tethyidae & Tethya aurantium (Pallas, 1766) & Dendy, 1905 \\
\hline 112 & Tetractinellida & Tetillidae & Tetilla poculifera Dendy, 1905 & Dendy, 1905 \\
\hline 113 & Haplosclerida & Petrosiidae & Xestospongia testudinaria (Lamarck, 1815) & Dendy, 1905; Mahadevan \& Nayar, 1967 \\
\hline 114 & Haplosclerida & Petrosiidae & Xestospongia muta (Schmidt, 1870) & New record, Present study \\
\hline
\end{tabular}

of this area. The barrel sponges are one of the best known for their ability to filter huge quantities of sea water and harbours proteobacterial and cyanobacterial endosymbionts in their mesohyl, which plays an essential role in cycling nutrients in the reefs. The microbes in the sponge and continuous filtration of sea water helps in the recycling of the nitrogen, carbon and other nutrients to the next trophic level (Rützler, 1990; Diaz and Rützler, 2001; Morrow et al., 2016; McMurray, 
2017). The frequent heavy storms and cyclones, mechanical damage to the sponge body, bleaching and disease of the sponges due to the climate change might have attributed to the decline in the population of barrel sponges. At the same time, the area of incrustation was found to increase by the encrusting sponge species like Clathria (Clathria) indica in the coral and paar areas. It was noticed that the Cup coral of this area was heavily encrusted by the Clathria species. Reason for the bleaching of the Coral may be due to the poor water quality and temperature variation.

\section{Boring sponges}

The most common boring sponges recorded from this area were Amorphinopsis excavans Carter, 1887 (Plate III, Fig.2); Cliona celata Grant, 1826 (Plate III, Fig.4); Cliona orientalis Thiele, 1900; Cliona delitrix Pang, 1973; Cliothosa aurivillii (Lindgren, 1897); Spirastrella cunctatrix Schmidt, 1868; Spirastrella coccinea (Duchassaing \& Michelotti, 1864) (Plate III, Fig.1); Spheciospongia inconstans (Dendy, 1887); Spheciospongia vesparium (Lamarck, 1815); Spheciospongia vagabunda (Ridley, 1884) and Cervicornia cuspidifera (Lamarck, 1815) which were attached to different hosts like Corals (Pocillopora damicorinis), Mollusc shells (Crassostrea madrasensis, Xancus pyrum, Turbo intercostalis, Hemifusus cochlidium, Rapana bulbosa, Strombus sp., Babylonia spirata, Murex virgineus, M. tarpa, M. ramosus, Placuna placenta, Crassostrea cucullata, Pinctada fucata, Cardium spp., Conus spp., Chaina reflexa), calcareous algae and coralline algae. Past studies revealed that boring sponges caused damage to the pearl oyster beds and coral reefs along the Tuticorin coast (Dendy, 1905; Nayar and Mahadevan, 1987; Thomas, 1993, 2000; Anita and Lazarus, 2006).

The Tuticorin coast from Vaipar to Manappad contains about 33 Pearl oyster beds (Paars) falling into four zones, and the largest one is Tholayiram Paar. The average depth of the paar is 10-23 $\mathrm{m}$ and the area ranged from 1 to $20 \mathrm{~km}^{2}$. Variations observed in the nature of the substratum as flat rock, rocky and coral bed, rocky and sandy, rocky and shells, sandy with rocks, rock with crevices and sandy with muddy (Varma, 1960). The high diversity in the substrata resulted in the ecosystem services which resulted in the species variation in the corals, sponges and associated fauna. Past underwater observation of these paars reported the presence of species of boring sponges (Dendy, 1905; Nayar and Mahadevan, 1987). The major reason for the decline of the Pearl fishery along the coast may be attributed to the high exploitation through intensive fishery, damage caused by the boring sponges, predation and disease (Hornell, 1905; Thomas, 1993, 2000).

The present study reported 18 new records from the Tuticorin coast and resulted in the collection and preservation of 192 sponge specimens and reference specimens were deposited in the National Repository, Marine Biodiversity Museum in CMFRI, Kochi. The previous studies along the coast revealed a lot of information about species diversity, ecological diversity, biodiversity loss, boring sponges and fauna of pearl oyster beds and sponge - coral interactions (Dendy, 1905; Nayar and Mahadevan, 1987; Thomas, 1993, 2000; Anita and Lazarus, 2006). The new information about the massive sponges and boring sponges along the coast will be useful for the conservation of the biodiversity of the coasts.

Hornell's report (1905) on the sponge fauna in the pearl oyster bed gives a clear understanding of the different species of sponges, diversity, habitat types and distribution pattern of sponges during 1889 along the different habitats of Tuticorin area. The exploratory surveys conducted in the different paar groups of Vaipar, Tuticorin, Utti, Tolayiram, Pulipundu, Kanna Tivu, Nedunchechan, Kudamuttu, Thundu and Manapad resulted in the detailed account of the sponge species occurring in that area. Most abundant species reported by Hornell (1905) were Clathria (Clathria) indica, Spongionella nigra, Callyspongia (Euplacella) communis (=Siphonochalis communis), Spheciospongia inconstans (=Suberitus inconstans), Aulospongus tubulatus (=Axinella tubulata), Axinella donani, Xestospongia testudinaria $(=$ Petrosia testudinaria) and Neopetrosia similis (=Petrosia smilis). Besides this, a total of 78 species were reported from this area of Gulf of Mannar.

Out of the underwater exploration conducted by Nayar and Mahadevan $(1964,1974)$ important information about the sponges of Tuticorin emerged. These extensive surveys revealed the presence of about 77 species of sponges from different pearl oyster paars of Tuticorin (Mahadevan and Nair, 1967, 1974 Nayar and Mahadevan, 1964, 1987). The most abundant species reported by their studies were Callyspongia (Euplacella) communis, Spongionella nigra, Petrosis testudinaria, Spheciospongia inconstans, Aulospongia tubulatus, Amphimedon subcylindrica, Stylissa carteri (=Axinella carteri), lotrcoha spp., Clathria spp., Axinella donani, Clathria indica and Spheciospongia inconstans.

Thomas (1986) provided a detailed account of the sponge fauna of Gulf of Mannar and Palk Bay. A total of 275 species belonging to eight orders 38 families and 136 genera were reported. His study covered the localities of Gulf of Mannar from Rameswaram to Tuticorin and the study reported all the sponges recorded in the Tuticorin area of GOM in the previous works as well as new species described by the author (Thomas, 1971, 1986). Anita and Lazraus (2006) studied 50 species of sponges belonging to six orders, 16 families and 28 genera from Gulf of Mannar ecosystem. 
The Report on the Pearl oyster fisheries recorded that boring sponges are the enemy of Pearl oysters (Hornell, 1905). The species reported was Cliona margaritifera. Considerable work on the systematics and distribution pattern during the nineteenth century revealed the presence of 32 species of boring sponges from Indian seas with an order of abundance, such that Cliona celata, Pione vastifica and Pione carpenteri on chanks; Pione vastifica and Cliona celata on pearl oysters; Cliona celata, Pione vastifica and Pione carpenteri on edible oysters; Cliona celata, Cervicornia cuspidifera, Spheciospongia inconstans and Cliothosa aurivillii on corals (Nayar and Mahadevan, 1987; Thomas, 1979).

The bioinventorying and updating the status of the ecological services provided by the sponge fauna has to continue to get more insight into the present species composition and the interaction between the species and communities occurring in the vast variety of habitats. Sponges are known for its multifold ecological goods and services. The policy formulations can be made using the ecological services provided by the sponge fauna of the coast. Commercial utilization of sponges for several purposes, including extraction of bioactive components is the major provisioning service provided by sponges. Its regulatory services include the filtration of water through canal system which regulates water quality of an area. It supports several other organisms as a source of habitat and place for living and protection.

\section{Acknowledgements}

Authors are grateful to Ministry of Environment, Forest and Climate Change, New Delhi for the Financial Support in the form AICOPTAX project (22018.15 (1) 2015-CS (TAX) on Taxonomical Investigation on Lesser Known Marine Animals of India - Phylum Cnidaria (Class: Anthozoa) Phylum Porifera (Marine). Special thanks to Dr. Kailash Chandra, Director and Dr. C. Raghunathan, Joint Director, Zoological Survey of India, Kolkata for support provided. We acknowledge the sincere help provided by Dr. P. P. Manojkumar, SIC, Tuticorin during the Sponge Surveys we conducted in Gulf of Mannar.

\section{References}

Alcolado, P. M. and L. Busutil. 2012. Inventory of neritic sponges in La Guadeloupe National Park. Oceanol. Serie., 10:62-76

Alcolado, P.M. 1976. Lista de nuevos registros de Poriferos para Cuba.Serie Oceanológica. Instituto de Oceanologia. Academia de Ciencias de Cuba. Oceanologia, 36: 1-11.

Anita G. Mary and Lazarus.2006. An account on the marine sponges of Gulf of Mannar. GOMBRT Publication 5:56-61

Arndt, W. 1927. Kalk- und Kieselschwämme von Curaçao. Bijdr. Dierk. 25: 133-158.

Barnes D.K.A. and J.J. Bell. 2002. Coastal sponge communities of the West Indian Ocean: taxonomic affinities, richness and diversity. Afr. J. Ecol., 40: 337-349.

Bergquist, P. R. 1980. A revision of the supraspecific classification of the orders Dictyoceratidae, Dendroceratidae and Vergonida (Class Demospongiae). New Zeal. J. Zool., 7:443-503.

Bergquist, P.R., R.C. Cambie, and M.R. Kernan. 1990. Scalarane sesterterpenes from Collospongia auris, a new thorectid sponge. Biochem. Syst. Ecol., 18 (5): 349-357.
Borojevic, R. 1967. Spongiaires d'Afrique du Sud. (2) Calcarea. T. Roy.Soc. S. Afr., 37 (3): 183-226.

Borojevic, R., and P. Grua. 1965. Kerguelen limestone sponges. Systematics and ecology. Arch. Exp. Gen. Zool., 105 (1): 1-29.

Borojevic, R., L. Cabioch and C. Lévi. 1968. Inventaire de la faune marine de Roscoff. Spongiaires. Éditieur. Station Biolog. Roscoff. p.1-44.

Boury-Esnault, N. 1971. Sponges from the rocky area of Banyuls-sur-Mer. II. Systematique Vie.Milie. 22 (2): 287-349.

Boury-Esnault, N. 1973. Scientific Results of the 'Calypso' Campaigns. Campaign of the 'Calypso' off the Atlantic coast of South America, I. 29. Sponges. Ann. Oceanogr. Inst., 49: 263-295.

Boury-Esnault, N. and M.T. Lopes 1985. Coastal Demosponges of the Azores Archipelago. Annal. Oceanogr. Inst., 61 (2): 149-225.

Boury-Esnault, N., J.G. Harmelin, M. Ledoyer, L. Saldanha and H. Zibrowius 2001 [2005]. Peuplement benthique des grottes sous-marines de Sagres. In: Biscoito, M., A.J. Almeida \& P. Ré (Eds). A Tribute to Luiz Saldanha. Bol. Mus. Munic. Funchal. Sup., 6: 15-38.

Bowerbank, J.S. 1867. Sponges. In: Jeffreys, J.G., Hincks, T., Couch, J., Stewart, J., Rowe, J.B. \& Bate, J.S. Report to the committee appointed to explore the marine fauna and flora of the Devon and Cornwall, Rep. Br. Ass., 2: 275-286.

Bowerbank, J.S. 1872. Contributions to a General History of the Spongiadae. Part III. Proc. Zool. Soc. Lond., Part I :115-129, Part III: 626-635.

Bowerbank, J. S. 1875. Contributions to a General History of the Spongiadae. Part VII. Proc. Zool. Soc. Lond., : 281-296

Burton, M. 1930. Norwegian Sponges from the Norman Collection. Proc. Zool. Soc. Lond. 2: 487-546.

Burton, M. 1936. The fishery ground near Alexandria. IX. Sponges. Notes Mem.Fish. Res. Direct. Cairo., 17: 1-28

Burton, M. 1956. The sponges of West Africa. Atla. Rep., (Scientific Results of the Danish Expedition to the Coasts of Tropical West Africa, 1945-1946, Copenhagen) 4: 111-147.

Buznego, M. and P. M. Alcolado. 1987. Frecuencia de ataques de esponjas perforadoras sobre algunos corales escleractineos y otros susbtratros marinos en Cuba. Rep. Invest. Inst. Oceanol., 59 :1-13.

Carter, H.J. 1881. Contributions to our Knowledge of the Spongida. Ann. Mag. Nat. Hist., (5) 8: 101-259.

Carter, H.J. 1887. Report on the marine sponges, chiefly from King Island, in the Mergui Archipelago, collected for the Trustees of the Indian Museum, Calcutta, by Dr. John Anderson, F.R.S., Superintendent of the Museum. Zool. J. Linn. Soc. 21:61-84

Carter. H.J. 1885. Catalogue of marine sponge collected by Mr. Jos. Willcox on the west coast of Florida. Proc. Acad. Nat. Sci. Phil., 1884: 202-209.

Cook, S. C. and P.R. Bergquist. 2002. Family Spongiidae Gray, 1867. In Hooper, J. N. A \& R. W. M Van Soest (Eds) SystemaPorifera: A guide to the classification of sponges, Kluwer Academic, Plenum Publisher, New York, p. 847-863.

Dendy, 1905. Report on the sponges collected by Prof. Herdraan, at Ceylon in 1902. Rep. Govt. Ceylon Pearl Oyster Fish. Gulf Mannar Suppl. 18: 57-246.

Dendy, A. 1887. The sponge-fauna of Madras. A report on a collection of sponges obtained in the neighbourhood of Madras by Edgar Thurston, Esq. J. Nat. Hist., 20 (117):153-165.

Dendy, A. 1889. Report on a second collection of sponges from 299 the Gulf of Mannar. Ann. Mag. Nat. His. London, ser., 6 (3): 73-99.

Desor, E. 1848 (1851). Zoological Investigations among the shoals of Nantucket. Proc. Bost. Soc. Nat. Hist., 3: 11-68.

Desqueyroux-Faúndez, R. 1990. Sponges (Demospongiae) from Easter Island (Isla de Pascua) (South Pacific Ocean). Rev. Suisse. Zool., 97(2): 373-410.

Diaz, M.C. and K. Rützler. 2001. Sponges: an essential component of Caribbean coral reefs. Bull. Mar. Sci., 69(2): 535-546.

Duchassaing de Fonbressin, P., and G. Michelotti .1864. Sponges from the Caribbean Sea. Natuurk. Verh. Holland. Maatsch. Wet. Haarlem 21 (2): 1-124.

Ellis, J., D. Solander. 1786. The Natural History of many curious and uncommon Zoophytes, collected from various parts of the Globe. Systematically arranged and described by the late Daniel Solander. 4: 1-206.

Esper, E.J.C. 1794. Die Pflanzenthiere in Abbildungen nach der Natur mit Farben erleuchtet, nebst Beschreibungen. Zweyter Theil., p. 1-303.

Evcen, A. and M. E Çinar. 2012. Sponge (Porifera) species from the Mediterranean coast of Turkey (Levantine Sea, eastern Mediterranean), with a checklist of sponges from the coasts of Turkey. Turk. J. Zool., 36: 460-464.

Fabricius, 0. 1780. Fauna Groenlandica systematice sistens animalia Groenlandiae occidentalis hactenus indagata. Jo. Gottlob Rothe., 452 pp.

Ferrer Hernández, F. 1918. Asturias coastal sponges. Works of the National Museum of Natural Sciences Series Zoologia. 36: 1-39.

Fristedt, K. 1887. Sponges from the Atlantic and Arctic Oceans and the Behring Sea. Vega-Expeditionens Vetenskap. lakttagelser (Nordenskiöld) 4: 401-471.

George, W.C. and H.V. Wilson. 1919. Sponges of Beaufort (N.C.) Harbor and Vicinity. Bull. Bure.Fish., Washington. 36: 129-179. 
Grant, R.E. 1826. Notice of a New Zoophyte (Cliona celata Gr.) from the Firth of Forth. Edinburgh New Philos. J., 1: 78- 81

Green, G. 1977. Sinopsis taxonómica de trece especies de esponjas del arrecife La Blanquilla, Ver., México. An. Inst. Cienc. Mar. Limnol. Univ. Nac. Auton. Mex., 4(1): 79-98.

Haeckel, E. 1872. The lime sponges. A monograph in two volumes of text and an atlas with 60 plates and illustrations. G. Reimer: Berlin, 2: 1-418.

Hajdu, E., Peixinho, S. and J.C.C Fernandez. 2011. Esponjas marinhas da Bahia. Guia de campo e laboratório. Mus. Nac. Ser. Rio de Janeiro, p. 1-276.

Hechtel, G. J. 1965. A systematic study of the Demospongiae of Port Royal, Jamaica. Bull. Peabody Mus. Nat. Hist., 20: 1-103.

Henkel, D. and D. Janussen. 2011. Redescription and new records of Celtodoryx ciocalyptoides (Demospongiae: Poecilosclerida)-a sponge invader in the north east Atlantic Ocean of Asian origin? J. Mar. Biol. Ass. U. K., 91(2):347-355.

Hentschel, E. 1909. Tetraxonida. I. part. In: Michaelsen, W. \& Hartmeyer, R. (Eds), Die Fauna Südwest-Australiens. Results of the Hamburg Southwest Australian research trip 1905, 2 (21): 347-402

Herdman, W. A.1903-1906. Report to the Government of Ceylon on the Pearl oyster Fisheries of the Gulf of Mannar with supplementary reports upon the Marine Biology of Ceylon by naturalists. Royal Society, London: 1:1-307; 2:1-300; 3:1384; 4:1-326; 5:1-452.

Hooper, J.N.A. and R.W.M. Van Soest. 2002. Systema Porifera: a guide to the classification of Sponges. Kluwer Academic/ Plenum Publishers: New York, 2 Volumes. $1706 \mathrm{pp}$.

Hornell, J. 1905. Report to the Government of Madras on the Indian pearl fisheries in the Gulf of Mannar (Madras Govt, publication), 107pp.

Hornell, J. 1922. The Indian pearl fisheries of the Gulf of Mannar and Palk Bay. Madras Fish. Bull., $16: 1-188$.

Hyatt, A. 1875. Revision of the North American Poriferae; with Remarks upon Foreign Species. Part I. Mem. Boston Soc. Nat. Hist., 2: 399-408,

Idan T., S. Shefer, T. Feldstein, R. Yahel, D. Huchon and M. Ilan .2018. Shedding light on an East-Mediterranean mesophotic sponge ground community and the regional sponge fauna. Mediter.Mar. Sci., 19(1): 84-106.

Johnson, M.F. 1971. Some marine sponges of Northeast Brazil. Arq. Ciênc. Mar., 11(2): 103-116.

Kelly, M., A.R. Edwards, M.R. Wilkinson, B. Alvarez, S. de C. Cook, P.R. Bergquist, St J Buckeridge, H.J. Campbell, H.M. Reiswig, C. Valentine and J. Vacelet. 2009. Phylum Porifera: sponges. in: Gordon, D.P. (Ed.) (2009). New Zealand inventory of biodiversity: 1. Kingdom Animalia: Radiata, Lophotrochozoa, Deuterostomia. p. 23-46.

Kim, J.Y. and C.J. Sim. 2001. New record of two poecilosclerid sponges (Porifera, Demospongiae) from Korea. Korean J. Sys. Zool., 17 (1): 29-34.

Klautau, M., C. Valentine. 2003. Revision of the genus Clathrina (Porifera, Calcarea). Zool. J. Linn. Soc., 139(1): 1-62.

Lamarck, J.B.P. de M. 1815. Suite des polypiers empâtés. Mém. Mus. Natt. 'Hist. Nat. Paris, $1: 69-340$

Lamarck, J.B.P. de M.1814. Sur les polypiers empâtés. Suite du mémoire intitulé: Sur les polypiers empâtés. Suite des éponges. An. Mus. Natl. 'Hist. Nat. Paris, 20: 370-458.

Lambe, L.M. 1896. Sponges from the Atlantic coast of Canada. Trans. R. Soc. Can., 2 (2): $181-211$.

Laubenfels, M.W. de. 1936. A comparison of the shallow-water sponges near the Pacific end of the Panama Canal with those at the Caribbean end. Proc. U.S. Natl. Mus., 83 (2993): 441-466.

Laubenfels, M.W. de. 1950. The Sponges of Kaneohe Bay, Oahu. Pac. Sci, 4 (1): 3-36.

Laubenfels, M.W. de. 1953. Sponges from the Gulf of Mexico. Bul. Ma. Sci.Gulf Car., 2(3): 511-557.

Lendenfeld, R. 1889. A monograph of the horny sponges. Trübner and Co., London, $936 \mathrm{pp}$.

Lévi, C. 1952. Sponges from the coast of Senegal. Bull. Fren. Ins.Bla. Afr. (A. Natural Sciences). 14 (1): 34-59.

Lévi, C. 1957. Spongiaires des côtes d'Israel. Bull. Res. Coun. Israel. 6 B (3-4): 201 212.

Lévi, C. 1959. Scientific results of the 'Calypso' Campaigns. Ann. Oceanogr. Ins., 37 (4): 115-141.

Lévi, C. 1965. Spongiaires récoltés par l'expédition israélienne dans le sud de la Mer Rouge en 1962. Sea Fish. Res. St. Haifa Bull., 39 : 3-27.

Lévi, C. and J. Vacelet. 1958. Éponges récoltées dans l'Atlantique oriental par le 'Président Théodore-Tissier'. Rev. Trav. Inst. Pêches Mari., 22(2): 225-246.

Lindgren, N.G. 1897. Beitrag zur Kenntniss der Spongienfauna des Malaiischen Archipels und der Chinesischen Meere. Zool. Anz., 547: 480-487.

Logan, A. and S. M. Mathers and M. L. H. Thomas. 1984. Sessile invertebrate coelobite communities from reefs of Bermuda: species composition and distribution. Coral Reefs, 2: 205-213

Lombas, I. 1982. Distribución, de esponjas esciafilas en la zona intermareal de Aramar (Luanco, Asturias). Bol. Cienc. Nat. IDEA, 29: 37-50.
Longo, C., F. Mastrototaro and G. Corriero. 2007. Occurrence of Paraleucilla magna (Porifera: Calcarea) in the Mediterranean sea. J. Mar. Biol. Ass. U. K., 87(6):1749-1756.

Mahadevan, S and K. Nagappan Nayar. 1967. Underwater ecological observations in the Gulf of Mannar off Tuticorin-VII. General topography and ecology of the rocky bottom. J. Mar. Biol. Ass. India, 9 (1): 147-165.

Mahadevan, S and K. Nagappan Nayar. 1974. VII Ecology of Pearl Oyster and Chank beds. In: CMFRI Bulletin No.25, The Commercial molluscs of India. CMFRI, Mandapam Camp, p. 106-121.

McMurray S.E, J.R. Pawlik and C.M. Finelli. 2017. Demography alters carbon flux for a dominant benthic suspension feeder, the giant barrel sponge, on Conch Reef, Florida Keys. Funct. Ecol., 31: 2188-2199

Montagu, G. 1814. An Essay on Sponges, with Descriptions of all the Species that have been discovered on the Coast of Great Britain. Mem. Wern. Nat. Hist. Soc., 2 (1): 67-122.

Morrow, K. M., Cara L. Fiore and M. P. Lesser. 2016. Environmental drivers of microbial community shifts in the giant barrel sponge, Xestospongia muta over a shallow to mesophotic depth gradient. Environ. Microbiol., 18(6):2025-38.

Mothes, B. and M.C.K. Bastian. 1993. Esponjas do Arquipélago de Fernando de Noronha Brasil (Porifera, Demospongiae). Iherengia (Zool.) Porto Alegre. 75: 15-31.

Muricy, G., D.A. Lopes, E. Hajdu, M.S. Carvalho, F.C. Moraes, M. Klautau, C. Menegola and U. Pinheiro. 2011. Catalog of Brazilian Porifera. Natl. Mus. Books Series. 300 pp.

Muricy, G., E.L. Esteves, F.C. Moraes, J.P. Santos, S.M. da Silva, M. Klautau and E. Lanna. 2008. Marine Biodiversity of the Potiguar Basin. Nat. Mus. Rio de Janeiro, Books Series. 29, 156 pp.

Nayar, K Nagappan and S. Mahadevan. 1964. Underwater ecological observations in the Gulf of Mannar, off Tuticorin-II. The Occurrence of the Synaptid Chondrocloea along with the Massive Sponge, Petrosia. J. Mar. Biol. Ass. India, 7 (1): 199-200.

Nayar, K Nagappan and S. Mahadevan. 1987. Ecology of pearl oyster beds. CMFRI Bulletin-Pearl culture, 39: 29-38.

Pang, R. K. 1973. The systematics of some Jamaican excavating sponges (Porifera). Postilla. 161: 1-75: 42-47.

Perez, T., B. Perrin, S. Carteron, J. Vacelet and N. Boury-Esnault. 2006. Celtodoryx girardae gen. nov. sp. nov., a new sponge species (Poecilosclerida: Demospongiae) invading the Gulf of Morbihan (North East Atlantic, France). Cah. Biol. Mar., 47(2), p.205.

Pérez, T., M.C. Díaz, C. Ruiz, B. Cóndor-Luián, M. Klautau, E. Hajdu, G. Lôbo-Hajdu, S. Zea, S. A. Pomponi, R.W. Thacker, S. Carteron, G. Tollu, A. Pouget-Cuvelier, P. Thélamon, J. P. Marechal, O.P. Thomas, A. E. Ereskovsky, J. Vacelet and N. BouryEsnault. 2017. How a collaborative integrated taxonomic effort has trained new spongiologists and improved knowledge of Martinique Island (French Antilles, eastern Caribbean Sea) marine biodiversity. PLOS ONE. 12 (3): e0173859.

Poiret, J.L.M. 1789. Voyage en Barbarie, or Letters Written from Ancient Numidia during the Years 1785 and 1786, with an Essay on the Natural History of this Country. Second part. p. 1-315

Ridley, S.O. 1881. XI. Spongida. Horny and Siliceous Sponges of Magellan Straits, S.W. Chili, and Atlantic off SW Brazil. in: Account of the Zoological Collections made during the Survey of H.M.S. 'Alert' in the Straits of Magellan and on the Coast of Patagonia. Gunther, A. (Ed.). Proc. Zool. Soc. Lond., p. 107-141.

Ridley, S.O. 1884. Spongiida. In: Report on the Zoological Collections made in the Indo-Pacific Ocean during the Voyage of sponges from cryptic habitats on the belize barrier reef 127 H.M.S. 'Alert', 1881- 2. British Museum (Natural History), London), p. 366-630.

Ridley, S.O. and A. Dendy. 1886. Preliminary report on the Monaxonida collected by H.M.S. 'Challenger'. Ann. Mag. nat. Hist., Series 5, 18: 325-493.

Rützler, K. 1965. Systematik und Ökologie der Poriferen aus Litoral-Schattengebieten der Nordadria. Z. Morphol. Ökol. Tiere. 55(1): 1-82.

Rützler, K. 1974. The Burrowing Sponges of Bermuda. Smith. C. Zool., 165: 1-32.

Rützler, K. 1986. Phylum Porifera (Sponges). In: W. Sterrer (Ed.) Marine Fauna and Flora of Bermuda. John Wiley \& Sons, New York, p. 111-126.

Rützler, K. 1990. Associations between Caribbean sponges and photosynthetic organisms. In: Rützler K (Ed) New perspectives in sponge biology. Smithsonian Institution Press, Washington, DC: 455- 466

Rützler, K., C. Piantoni, R.W.M. Van Soest and M.C. Díaz. 2014. Diversity of sponges (Porifera) from cryptic habitats on the Belize barrier reef near Carrie Bow Cay. Zootaxa. 3805(1): 1-129.

Rützler, K., M.C. Díaz, R.W.M. van Soest, S. Zea, K. P. Smith, B. Alvarez and J. Wulff. 2000. Diversity of sponge fauna in mangrove ponds, Pelican Cays, Belize. Atoll Res. Bull., 476: 230-248.

Rützler, K., R. W. M van Soest and C. Piantoni. 2009. Sponges (Porifera) of the Gulf of Mexico. in: Felder, D.L. and D.K. Camp (eds.), Gulf of Mexico- Origins, Waters, and Biota. Biodiversity. Texas A \& M Press, College Station, Texas, p. 285-313.

Sarà, M . and L. Siribelli. 1960. The fauna di Poriferi delle 'secche' del Golfo di Napoli. 1. The 'secca' della Gaiola. Annu. Mus. Zool.'Univ., Napoli, 12 (3): 1-93. 
Sarà, M. 1961. The fauna of Poriferi in the caves of the Tremiti islands. Ecological and systematic study. Ital. Zool. Arch., 46: 1-59.

Schmidt, 0. 1862. The sponges of the Adriatic Sea. (Wilhelm Engelmann: Leipzig): 1-88.

Schmidt, 0. 1864. Supplement of the sponges of the Adriatic Sea. Contains the histology and systematic additions. (Wilhelm Engelmann: Leipzig), p. 1-48.

Schmidt, 0. 1868. Die Spongien der Küste von Algier. Mit Nachträgen zu den Spongien des Adriatischen Meeres (Drittes Supplement). Wilhelm Engelmann, Leipzig, $44 \mathrm{pp}$.

Schmidt, 0. 1870. Basic features of a spongy fauna of the Atlantic area. (Wilhelm Engelmann: Leipzig), p. 1-88.

Schulze, F.E. 1880. Investigations into the construction and development of the sponges. Ninth communication. The Plakinids. J. Sci. Zool., 34 (2): 407-451.

Sivaleela, G. 2014. Marine sponges of Gulf of mannar and Palk Bay. Rec. Zool. Surv. India, 114(4): 607-622.

Stephens, J. 1912. A Biological Survey of Clare Island in the County of Mayo, Ireland and the Adjoining District. Marine Porifera. Proc. R. Ir. Acad., 31 (3):1-42.

Tendal, O.S. 1970. De Danske Peary Land Ekspeditioner, I. Sponges from Jørgen Brønlund Fjord, North Greenland. Medd. Grøn.

Thiele, J. 1900. Kieselschwämme von Ternate. I. Abh. Senckenb. Naturforschenden Gese. Frankfurt. 25: 19-80

Thomas, P. A.1971. On some deep sea sponges from the Gulf of Mannar, with descriptions of three new species. J. Mar. Biol. Ass. India, 12 (1\&2): 202-209.

Thomas, P. A .1979. Boring sponges destructive to economically important Molluscan beds and coral reefs in Indian seas. Indian J. Fish., 26 (1\&2): 163-200.

Thomas, P.A. 1979. Studies on sponges of the Mozambique channel. I. Sponges of the Inhaca Island. II. Sponges of Mambone and Paradise Islands. Ann. Musée. Roy.'Afr.Cent. Terv. Sci. Zool., 227: 1-73.

Thomas, P.A. 1981. A second collection of marine Demospongiae from Mahe Island in the Seychelles Bank (Indian Ocean). Ann. Musée.Roy.'Afr.Cent. Terv. Sci. Zool., 233: 1-63.

Thomas, P. A.1986. Demospongiae of the Gulf of Mannar and Palk Bay. In: Recent Advances in Marine Biology. Today and Tomorrow Printers and Publishers, New Delhi, p. 205-366.

Thomas, P. A. 2000. Sponges- systematics, as pests of molluscs, agents of bioerosion and a source of bioactive compounds. In: Marine Fisheries Research and Management. CMFRI, p. 109-123.

Thomas, P. A., K. Ramadoss and S.G. Vincent. G.1993. Invasion of Cliona margaritifera Dendy and C. lobata Hancock on the molluscan beds along the Indian coast. J. Mar. Biol. Ass. India, 35 (1\&2): 145-156.

Topsent, E. and L. Olivier. 1943. Eponges observées in the parages de Monaco (fin). Bull.Inst. Océanogr. Monaco. 854: 1-12.

Topsent, E. 1891. Voyage of the Goëlette 'Melita' to the Canaries and Senegal, 18891890. Sponges. Memoir. Zool. Soc. Fr., 4: 11-15.

Topsent, E. 1892. Contribution to the study of sponges from the North Atlantic (Bay of Biscay, Newfoundland, Azores). Results of scientific campaigns carried out by Prince Albert I. Monaco, 2: 1-165.

Topsent, E. 1892. Diagnosis of new sponges from the Mediterranean and more particularly from Banyuls. Arch. Exp.Gen. Zool., (2) 10.

Topsent, E. 1897. Sponges from Amboine Bay. (Voyage of Messrs. M. Bedot and C. Pictet in the Malay Archipelago). Swiss J. Zool., 4: 421-487.

Topsent, E. 1928. Sponges from the Atlantic and Mediterranean from the cruises of Prince Albert I of Monaco. Results of scientific campaigns carried out by Prince Albert I. Monaco, 74: 1-376.
Topsent, E. 1934. Sponges observed in the vicinity of Monaco. (First part). Bull. Oceanogr. Inst., Monaco, 650: 1-42.

Trott, T. J. 2004. Cobscook Bay inventory: a historical checklist of marine invertebrates spanning 162 years. Northeast. Nat., 11: 261-324.

Vacelet, J., P. Vasseur and C. Lévi 1976. Sponges of the outer slope of the coral reefs of Tulear (southwestern Madagascar). Memior. Natt. Mus. Nat. Hist. (A, Zoology). 49: 1-116.

Van Soest, R.W.M. 1978. Marine sponges from Curaçao and other Caribbean localities. Part I. Keratosa. In: Hummelinck, PW \& Van der Steen, $\mathrm{U}$ (Eds), Editions of the Natural Sciences Study Circle for Suriname and the Netherlands Antilles. No. 94. Studies on the Fauna of Curaçao and other Caribbean Islands. 56 (179): 1- 94.

Van Soest, R.W.M. 1980. Marine sponges from Curaçao and other Caribbean localities. Part II. Haplosclerida. In: Hummelinck, P.W. \& Van der Steen, L.J. (Eds), Uitgaven van de Natuurwetenschappelijke Studiekring voor Suriname en de Nederlandse Antillen. No. 104. Studies on the Fauna of Curaçao and other Caribbean Islands. 62 (191): 1-173.

Van Soest, R.W.M. 1981. A checklist of the Curaçao sponges (Porifera Demospongiae) including a pictorial key to the more common reef-forms. Versl. Techni.Gege. Inst. Taxon. Zoöl. (Zoöl. Mus.) Univ. Amst., 31: 1-39

Van Soest, R.W.M. 1984. Marine sponges from Curaçao and other Caribbean localities. Part III. Poecilosclerida. In : Hummelinck, PW \& Van der Steen, L (Eds), Editions of the Natural Sciences Study Circle for Suriname and the Netherlands Antilles. No. 112. Studies on the Fauna of Curaçao and other Caribbean Islands. 66 (199): 1-167.

Van Soest, R.W.M. 1993. Affinities of the Marine Demospongiae Fauna of the Cape Verde Islands and Tropical West Africa. Cou. Forsch. Senck., 159: 205-219.

Van Soest, R.W.M. 2001. Porifera, in: Costello, M.J. et al., European register of marine species: a check-list of the marine species in Europe and a bibliography of guides to their identification. Coll. Patri. Nat., 50: 85-103.

Van Soest, R.W.M. 2017. Sponges of the Guyana Shelf. Zootaxa. 4217: 1-225.

Van Soest, R.W., M.J. De Kluijver, P.H. Van Bragt, E.J. Beglinger, W.H. De Weerdt and N.J. De Voogd. 2007. Sponge invaders in Dutch coastal waters. J. Mar. Biol. Ass. U. K., 87(6): 1733-1748.

Van Soest, R.W.M. and N. J. De Voogd, 2015. Calcareous sponges of Indonesia. Zootaxa. 3951(1): 1-105.

Van Soest, R.W.M. and N.J. De Voogd. 2018. Calcareous sponges of the Western Indian Ocean and Red Sea. Zootaxa. 4426 (1): 1-160.

Van Soest, R.W.M., N. Boury-Esnault, J. N .A. Hooper, K. Rützler, N.J. de Voogd, B.Alvarez, E. Hajdu, A. B. Pisera, R. Manconi, C. Schönberg, M. Klautau, M. Kelly, J. Vacelet, M. Dohrmann, M. C. Díaz, P. Cárdenas, J. L. Carballo, P. Ríos, R. Downey and C.C. Morrow. 2020. World Porifera Database.

Varma, R Prasanna .1960. Flora of the pearl beds off Tuticorin. J. Mar. Biol. Ass. India, 2 (2): $221-225$

Vine, P. 1986. Red Sea Invertebrates. Immel Publishing, London, 224 pp.

Voigt, O., D. Erpenbeck, R.A., González-Pech, A.M. Al-Aidaroos, M.L. Berumen, and G. Wörheide. 2017. Calcinea of the Red Sea: providing a DNA barcode inventory with description of four new species. Mar. Biodivers. 47 (4): 1009- 1034.

Whitelegge, T. 1901. Report on sponges from the coastal beaches of New South Wales. Reco. Aust. Mus., 4 (2): 55-118.

Wiedenmayer, F. 1977. Shallow-water sponges of the western Bahamas. Exp. Suppl., 28: 1-287.

Zea, S. 1987. Esponjas del Caribe Colombiano. (Catálogo Cientifico: Bogotá, Colombia): p. 1-286. 